\title{
Actions of Bupivacaine, a Widely Used Local Anesthetic, on NMDA Receptor Responses
}

\author{
Meaghan A. Paganelli ${ }^{1}$ and ${ }^{\circledR G}$ Gabriela K. Popescu ${ }^{1,2}$ \\ ${ }^{1}$ Neuroscience Program and the ${ }^{2}$ Department of Biochemistry, School of Medicine and Biomedical Sciences, University at Buffalo, Buffalo, New York 14214
}

\begin{abstract}
NMDA receptors mediate excitatory neurotransmission in brain and spinal cord and play a pivotal role in the neurological disease state of chronic pain, which is caused by central sensitization. Bupivacaine is the indicated local anesthetic in caudal, epidural, and spinal anesthesia and is widely used clinically to manage acute and chronic pain. In addition to blocking $\mathrm{Na}^{+}$channels, bupivacaine affects the activity of many other channels, including NMDA receptors. Importantly, bupivacaine inhibits NMDA receptor-mediated synaptic transmission in the dorsal horn of the spinal cord, an area critically involved in central sensitization. We used recombinant NMDA receptors expressed in HEK293 cells and found that increasing concentrations of bupivacaine decreased channel open probability in GluN2 subunit- and pH-independent manner by increasing the mean duration of closures and decreasing the mean duration of openings. Using kinetic modeling of one-channel currents, we attributed the observed current decrease to two main mechanisms: a voltagedependent "foot-in-the-door" pore block and an allosteric gating effect. Further, the inhibition was state-independent because it occurred to the same degree whether the drug was applied before or after glutamate stimulation and was mediated by extracellular and intracellular inhibitory sites, via hydrophilic and hydrophobic pathways. These results predict that clinical doses of bupivacaine would decrease the peak and accelerate the decay of synaptic NMDA receptor currents during normal synaptic transmission. These quantitative predictions inform possible applications of bupivacaine as preventative and therapeutic approaches in chronic pain.
\end{abstract}

Key words: electrophysiology; local anesthetics; NMDA; pain; single-channel

\section{Introduction}

Local anesthetics are widely used in clinical practice to prevent and alleviate pain during surgery; however, their mechanisms of action are complex and incompletely understood. In addition to a prominent blocking effect on voltage-gated $\mathrm{Na}^{+}$channels, local anesthetics also modulate many other neuronal channels (Hara et al., 1995; Scholz, 2002). Recent studies demonstrated that bupivacaine, the local anesthetic most commonly used for spinal, epidural, and caudal anesthesia, inhibits NMDA receptor currents, thus raising the possibility that this inhibition may account for some of its specific clinical effects (Nishizawa et al., 2002; Sugimoto et al., 2003; Hahnenkamp et al., 2006; Furutani et al., 2010).

NMDA receptors are critical for the plastic events in the dorsal horn underlying central sensitization (Ji and Woolf, 2001). Given that inhibiting NMDA receptor currents is an effective strategy in prevention and management of chronic pain syndromes (South

\footnotetext{
Received Aug. 26, 2014; revised 0ct. 28, 2014; accepted Nov. 22, 2014.

Author contributions: M.A.P. and G.K.P. designed research; M.A.P. performed research; G.K.P. contributed unpublished reagents/analytic tools; M.A.P. analyzed data; M.A.P. and G.K.P. wrote the paper.

This work was supported by the NIH (R01NS052669 to GKP, and F31NS076235 to MAP). We thank Ms. Eileen Kasperek for technical assistance with molecular biology and cell culture, Dr. Jim Hitt for initiating and advice with this line of investigation, and Drs. Malcolm Slaughter, Mike Morales, and Matthew Xu-Friedman for valuable feedback while this work was in progress.

The authors declare no competing financial interests.

Correspondence should be addressed to Dr. Gabriela K. Popescu, Department of Biochemistry, University at Buffalo, 140 Farber Hall, 3435 Main Street, Buffalo, NY 14214. E-mail: popescu@buffalo.edu.

DOI:10.1523/JNEUROSCI.3578-14.2015

Copyright $\odot 2015$ the authors $\quad 0270-6474 / 15 / 350831-12 \$ 15.00 / 0$
}

et al., 2003; Rondon et al., 2010; Woolf, 2010), bupivacaine, which is safe and long-lasting, may represent a useful treatment of central sensitization resulting pathologies. NMDA receptors are heterotetramers of two GluN1 and two GluN2 subunits (Karakas and Furukawa, 2014; Lee et al., 2014). Each subunit contains ligand- and allosteric modulator-binding extracellular domains, a transmembrane domain composed of three membranespanning helices (M1, M3, M4) and a P-loop (M2), and a large intracellular domain. Relative to $\mathrm{Na}^{+}$channels, the topology of NMDA receptors is reversed, with an external ligand-controlled gate, and the narrowest region of the pore located two-thirds into the membrane field. The permeation pathway is lined by residues on M3 helices and M2 loops of each subunit, and these form binding sites for divalent cations (Nowak et al., 1984) and other blocking molecules (Huettner and Bean, 1988; Bormann, 1989; Parsons et al., 1993; Sobolevsky et al., 1999). NMDA receptor currents can be reduced by pore blockers, which obstruct the permeation pathway in a voltage-dependent manner, and by allosteric modulators, which alter channel gating kinetics (Kawajiri and Dingledine, 1993; Popescu, 2005; Traynelis et al., 2010).

In spinal cord slices, bupivacaine reduces NMDA-elicited whole-cell currents from dorsal horn neurons with potency in the low micromolar range (Furutani et al., 2010), which is well within spinal cord CSF concentrations $(0.1-3.0 \mathrm{~mm})$ following clinical doses of bupivacaine (Ruppen et al., 2009). Studies of recombinant NMDA receptors expressed in oocytes suggested that bupivacaine inhibition lacks voltage dependence and concluded that it acts solely as a noncompetitive, allosteric inhibitor (Sugimoto et 
al., 2003); additionally, an indirect PKC-mediated mechanism has also been implicated (Hahnenkamp et al., 2006). Using electrophysiology and kinetic modeling for GluN1/GluN2A receptors expressed in HEK293 cells, we found that bupivacaine inhibition was fully explained by a concentration-dependent reduction in receptor open probability, which was due to combined shorter open and longer closed durations. Overall, this effect was voltage-dependent and state-independent; involved extracellular and intracellular access sites; and was best described by combined channel-block and allosteric mechanisms. The state model developed with this work represents a new quantitative tool to evaluate the mechanisms by which bupivacaine can prevent, manage, or perhaps reverse central sensitization.

\section{Materials and Methods}

Cell culture and receptor expression. HEK293 cells were maintained in DMEM (Invitrogen) supplemented with $10 \% \mathrm{FBS}$ at $37^{\circ} \mathrm{C}$ in $5 \% \mathrm{CO}_{2}$ atmosphere. Cells were plated in $35 \mathrm{~mm}$ dishes $24 \mathrm{~h}$ before transfections at a density of $\sim 10^{5}$ cells/dish.

Rat GluN1 (UO8261) and GluN2A (M91561) or GluN2B (M91562) subunits were expressed from pcDNA3.1. Plasmids were transiently transfected at a GluN1:GluN2:GFP ratio of 1:1:1 using the calcium phosphate method (Chen and Okayama, 1987; Kussius et al., 2009). After 2 h of incubation, the transfection mixture was replaced with DMEM supplemented with $2 \mathrm{mM} \mathrm{Mg}^{2+}$ to prevent excitotoxicity. Cells were used for electrophysiological recordings $24-48 \mathrm{~h}$ after transfection.

Electrophysiology. Whole-cell currents were recorded with firepolished pipettes $(4-6 \mathrm{M} \Omega$ ) filled with intracellular solution containing the following (in mM): $135 \mathrm{CsF}, 33 \mathrm{CsOH}, 2 \mathrm{MgCl}_{2}, 1 \mathrm{CaCl}_{2}, 10 \mathrm{HEPES}$, 11 EGTA at $\mathrm{pH} 7.4$ (with $\mathrm{CsOH}$ ). Extracellular solutions contained the following (in $\mathrm{mm}$ ): 1 glutamate, 0.1 glycine, $150 \mathrm{NaCl}, 2.5 \mathrm{KCl}, 0.01$ EDTA, $10 \mathrm{HEPES}, 0.5 \mathrm{CaCl}_{2}$, without (control) or with bupivacaine at pH 7.4 or 8.0 (with $\mathrm{NaOH}$ ) and were applied onto cells clamped at -70 $\mathrm{mV}$ or as indicated, using a solenoid valve-controlled pressurized perfusion system (ALA-VM8, ALA Scientific Instruments), which has a solution exchange rate of $\sim 200-400 \mathrm{~ms}$. Current-voltage relationships were determined by stepping the holding potential in $20 \mathrm{mV}$ increments from $-100 \mathrm{mV}$ to $60 \mathrm{mV}$ with an intracellular solution lacking $\mathrm{MgCl}_{2}$, to avoid intracellular $\mathrm{Mg}^{2+}$ block. Currents were amplified and filtered at $2 \mathrm{kHz}$ (Axopatch 200B), sampled at $5 \mathrm{kHz}$ (Digidata 1440A) and stored as digital files using pClamp10.2 software (Molecular Devices). Macroscopic current peak and steady-state levels and desensitization time constants were determined across voltage ramps using the pClamp 10.2 software based on the average of at least 5 traces recorded from each cell. Dose-response curves were obtained by fitting the Hill equation to the mean normalized steady-state current (OriginPro 9.1). Voltage dependence was estimated by fitting the measured fractional reduction in current across voltages with the equation below adapted from the Woodhull equation (Woodhull, 1973):

$$
\frac{\mathrm{I}_{\mathrm{B}}}{\mathrm{I}_{0}}=\frac{1}{1+\frac{[\mathrm{B}]}{\mathrm{K}_{\mathrm{d}}(0) \times \exp \left(\frac{\mathrm{z} \delta \times \mathrm{V} \times \mathrm{F}}{\mathrm{RT}}\right)}}
$$

where $\mathrm{B}$ is the blocker concentration, $\mathrm{K}_{\mathrm{d}}(0)$ is the blocker dissociation constant at $0 \mathrm{mV}, z$ is the blocker valence, $\delta$ is the fraction of the electrical field that the blocker encounters at its blocking site, $\mathrm{V}$ is the membrane potential, and $\mathrm{F}, \mathrm{R}$, and $\mathrm{T}$ refer to the conventional thermodynamic constants.

The value for $z \delta$ from the Woodhull equation was used to calculate the voltage required for an e-fold change using the following equation:

$$
z \delta=\left(\frac{R T}{F}\right) / V^{\mathrm{e}}
$$

Excised outside-out patches were assayed with the solutions described above for the whole-cell experiments and with or without $1 \mathrm{~mm}$ bupiva- caine at $\mathrm{pH}$ 8.0. Solutions, with and without glutamate, were quickly exchanged by moving the patch back and forth across the interface between the two solution streams with a piezoelectric translation system (Burleigh LSS-3100/3200). Open-tip pipette potentials were measured at the end of each experiment to confirm a solution exchange rate of $0.2-$ $0.4 \mathrm{~ms}$. Currents were low pass filtered at $5 \mathrm{kHz}$ (Axopatch 200B), sampled at $50 \mathrm{kHz}$ (Digidata 1440A), and stored as digital files with the pClamp10.2 software. Peak current amplitude, rise time (as 10-90\% of peak), and decay time (monoexponential fit) were measured in pClamp10.2.

Excised inside-out patches were assayed with internal solutions containing the following (in $\mathrm{mm}$ ): 1 glutamate, 0.1 glycine, $150 \mathrm{NaCl}, 2.5$ $\mathrm{KCl}, 10$ HEPES, and 1 EDTA at pH 7.4 (with $\mathrm{NaOH}$ ). External solutions containing the following (in mM): $150 \mathrm{CsCl}, 11$ EGTA, $10 \mathrm{HEPES}$ at $\mathrm{pH}$ 7.4 (with $\mathrm{CsOH}$ ) and $\pm 6.0 \mathrm{~mm}$ bupivacaine or QX-314 were perfused onto the exposed intracellular face of the membrane. In patches with $>5$ channels, current-voltage relationships were evaluated by $2 \mathrm{~s}$ voltage ramps $(100 \mathrm{mV}$ to $-100 \mathrm{mV})$. In patches with fewer than 3 channels, current-voltage relationships were evaluated from unitary currents recorded by stepping the holding potential in $20 \mathrm{mV}$ increments ( $>5 \mathrm{~s}, 100$ to $-60 \mathrm{mV}$ ). Currents were low-pass filtered at $2 \mathrm{kHz}$ (Axopatch 200B), sampled at $40 \mathrm{kHz}$ (Digidata 1440A), and stored as digital files using pClamp10.2 software. Bursts originating from one channel (no overlapping openings) were analyzed for mean duration of openings using the QuB software as described below for attached patches.

Cell-attached one-channel currents were recorded with fire polished pipettes (12-25 $\mathrm{M} \Omega$ ) containing the following (in $\mathrm{mm}$ ): 1 glutamate, 0.1 glycine, $150 \mathrm{NaCl}, 2.5 \mathrm{KCl}, 10 \mathrm{HEPBS}, 1 \mathrm{EDTA}$, without (control) or with bupivacaine, at pH 8.0 (with $\mathrm{NaOH}$ ) (Maki et al., 2014). Inward sodium currents were amplified and low-pass filtered at $10 \mathrm{kHz}$ with an applied pipette potential of $100 \mathrm{mV}$ with Axopatch 200B (Molecular Devices), sampled at $40 \mathrm{kHz}$ (NIDAQ board), and written into digital files using QuB software (www.qub.buffalo.edu). To determine voltage dependencies, segments lasting $\sim 2$ min were recorded sequentially while the pipette potential was stepped in $20 \mathrm{mV}$ increments between 100 and 20 $\mathrm{mV}$. Current-voltage relationships were calculated by fitting the data with a linear function (OriginPro 9.1).

Records originating from patches containing exactly one active channel were analyzed using the QuB software as described in detail previously (Kussius et al., 2009). Briefly, after filtering at $12 \mathrm{kHz}$, singlechannel traces were idealized using a segmental $k$-means algorithm based on a hidden Markov model (Qin et al., 1996). Subsequently, all the kinetic state modeling was done by fitting user-defined models to the idealized event list produced by segmental $k$-means, after imposing a dead-time of $0.15 \mathrm{~ms}$, with a maximum interval log likelihood algorithm (Qin et al., 1997). The best fitting model was selected using a cutoff threshold of $10 \log$ likelihood units per added state. Bursts were defined as periods of activity lacking events longer than a critical closed time value $\left(\mathrm{t}_{\text {crit }}\right)$, with $\mathrm{t}_{\text {crit }}$ calculated to have values in between the $\mathrm{E}_{3}$ (control) or $\mathrm{E}_{6}$ (bupivacaine) and $\mathrm{E}_{4}$ closed components (Magleby and Pallotta, 1983). Bupivacaine association and disassociation rate constants were calculated by globally fitting models across single-channel files obtained at several drug concentrations ( $n=3 /$ each).

Simulations. Macroscopic responses were simulated as the sum of time-dependent accretion of receptors in open states. All receptors (500, $10 \mathrm{pA}$ ) initially occupied the resting glutamate-free state and were simulated with a square jump into $1 \mathrm{~mm}$ glutamate. The glutamate binding and dissociation rate constants used were as previously measured for GluN1/GluN2A receptors in conditions similar to the ones used here (Popescu et al., 2004). Pulses of glutamate ( $1.0 \mathrm{~mm}, 5 \mathrm{~s}$ ) and bupivacaine $(1.0 \mathrm{~mm}, 5 \mathrm{~s})$ were applied simultaneously and currents were simulated with the following: (1) a simple model representing average channel behaviors (see Fig. $2 D$ ) or (2) a more complex tiered model, which included bupivacaine-free and bupivacaine-bound receptors (see Fig. $4 B$ ). To simulate glutamate-elicited responses in the continued presence of ambient bupivacaine, we used the average bupivacaine-bound model (see Fig. 2D) in which glutamate binding steps were appended to the closed state $\mathrm{C}_{3}$. 
A

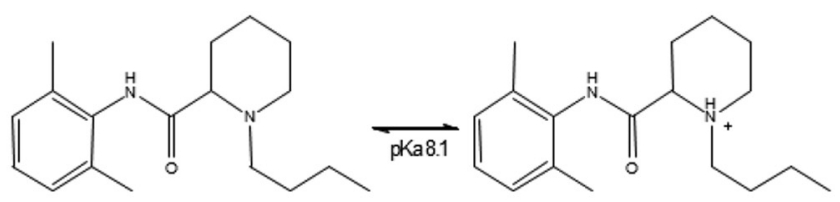

B

$$
\text { GluN1/GluN2A (-70 mV) }
$$

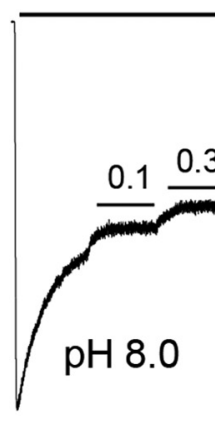

C
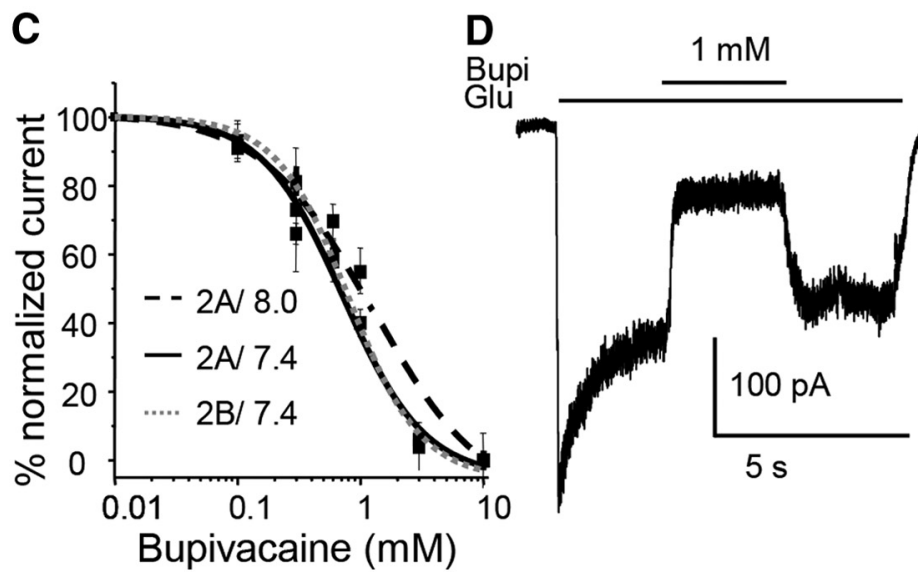

Figure 1. Bupivacaine reduced macroscopic currents of recombinant GluN1/GluN2 receptors. $A$, Bupivacaine structures and protonation equilibrium (Becker and Reed, 2006). $\boldsymbol{B}$, Whole-cell current traces recorded at $\mathrm{pH} 8.0$ (left) and 7.4 (right) from HEK 293 cells expressing GluN1/GluN2A receptors before and after applications of increasing concentrations of bupivacaine to the steady-state phase of the current. C, Concentration dependence of currents recorded at pH 8.0 (GluN2A) and 7.4 (GluN2A and GluN2B) was calculated by fitting the Hill function to the data. The $\mathrm{I}_{50}$ values were as follows: for GluN2A, $0.7 \pm 0.1 \mathrm{~mm}$ and $1.2 \pm 0.5 \mathrm{~mm}$ at pH $7.4(n=8)$ and pH $8.0(n=6)$, respectively; and for GluN2B, $0.8 \pm 0.1 \mathrm{~mm}$, at pH $7.4(n=3)$. D. Bupivacaine $(1.0 \mathrm{~mm})$ was applied to steady-state GluN1/GluN2A currents (pH 8.0, $-100 \mathrm{mV}$ ) to observe the kinetics of onset and recovery from inhibition $(n=6)$.

\section{Results}

\section{Effects of bupivacaine on macroscopic NMDA}

receptor responses

NMDA receptors are widely expressed in the spinal cord, including the dorsal horn, and are thought to be key players in the induction and maintenance of central sensitization (Ji et al., 2003). Bupivacaine reduces NMDA-induced whole-cell currents in dorsal horn spinal slices (Furutani et al., 2010). Similarly, bupivacaine reduces NMDA-induced currents in CA1 pyramidal cells and in recombinant receptors expressed in Xenopus oocytes, (Nishizawa et al., 2002; Sugimoto et al., 2003; Hahnenkamp et al., 2006). We set out to investigate this phenomenon on a microscopic level.

Because racemic bupivacaine and its enantiomers have similar potencies on NMDA receptors (Ueta et al., 2006), we used a racemic mixture in our study. Both GluN1/GluN2A and GluN1/ GluN2B receptor subtypes are highly expressed in the dorsal horn (Shiokawa et al., 2010). First, we tested the effect of bupivacaine on these receptor types by generating dose-response curves for the reduction in the whole-cell steadystate current levels of either GluN2A- or GluN2B-containing receptors, at physiological pH 7.4 (Fig. 1). Currents were elicited by applying glutamate $(1.0 \mathrm{~mm})$ in the continuous presence of glycine $(0.1 \mathrm{~mm})$, and bupivacaine was applied during the steady-state phase of the response at increasing concentrations. Half-maximal inhibition $\left(\mathrm{IC}_{50}\right)$ values calculated from the resulting dose-response relationship were similar for both receptor types investigated (GluN1/GluN2A, $0.7 \pm 0.1 \mathrm{~mm}$ vs GluN1/ GluN2B, $0.8 \pm 0.1 \mathrm{~mm}$ ) (Fig. $1 C$ ), consistent with previous studies in Xenopus oocytes (1.0 mM vs $1.1 \mathrm{~mm}$, respectively) (Sugimoto et al., 2003). For NMDA receptors, single-channel activity is best discerned at $\mathrm{pH}$ 8.0, where the natural proton inhibition of the receptor is minimal (Banke et al., 2005). Because the bupivacaine protonation equilibrium constant is within this range $(\mathrm{pKa}=8.1)$ (Fig. $1 A)$ (Becker and Reed, 2006), we also determined the doseresponse relationship at $\mathrm{pH}$ 8.0. For GluN1/GluN2A receptors, the $\mathrm{IC}_{50}$ values obtained at $\mathrm{pH} 7.4$ and $\mathrm{pH} 8.0$ were similar $(0.7 \pm 0.1$ and $1.2 \pm 0.6 \mathrm{~mm}$, respectively; $p>0.05$, one-way ANOVA) (Fig. $1 B, C)$. This result is consistent with previous reports showing that the bupivacaine effect on NMDA receptors was not charge-dependent (Hahnenkamp et al., 2006; Furutani et al., 2010). We conclude that, in our hands as well, bupivacaine inhibition of NMDA receptor responses was $\mathrm{pH}$ - and GluN2 subunit-independent.

As a last preparation for single-channel recordings, we estimated the kinetics of bupivacaine binding and dissociation. We recorded whole-cell responses $(\mathrm{pH} 8.0$, and $-100 \mathrm{mV}$ ) elicited by glutamate $(1.0$ $\mathrm{mm}$ ) applications (in the presence of glycine, $0.1 \mathrm{~mm}$ ) and pulsed $1 \mathrm{~mm}$ bupivacaine onto the steady-state phase of the current. We fit monoexponential functions to the onset and recovery phases of inhibition to calculate apparent association $\left(\mathrm{k}_{\mathrm{on}}\right.$, $\left.7 \pm 2 \times 10^{3} \mathrm{M}^{-1} \mathrm{~s}^{-1}\right)$ and dissociation $\left(\mathrm{k}_{\mathrm{off}}, 10 \pm 4 \mathrm{~s}^{-1}\right)$ rate constants as the inverse values of the measured time constants (Fig. 1D); these rate constants predicted a $\mathrm{K}_{\mathrm{d}}$ of $1.5 \mathrm{~mm}$, which is consistent with the $\mathrm{IC}_{50}$ value calculated from the whole-cell steadystate current inhibition. These measurements indicate that the onset of bupivacaine inhibition is several orders of magnitude slower than the reported kinetics of glutamate binding $\left(1.7 \pm 2.4 \times 10^{7} \mathrm{M}^{-1}\right.$ $s^{-1}$ ) (Popescu et al., 2004). Based on these results, we anticipated that, in steady-state high concentrations of glutamate (1 mM), as during on-cell single-channel investigations, glutamate dissociation will go undetected and the record will reflect at all times glutamatebound conformations; in contrast, when using bupivacaine concentrations around or lower than its measured $\mathrm{K}_{\mathrm{d}}$, the record will reflect the gating of both bupivacaine-bound and bupivacaine-free receptors, and the relative proportion of these will depend on the bupivacaine concentration used. 
A

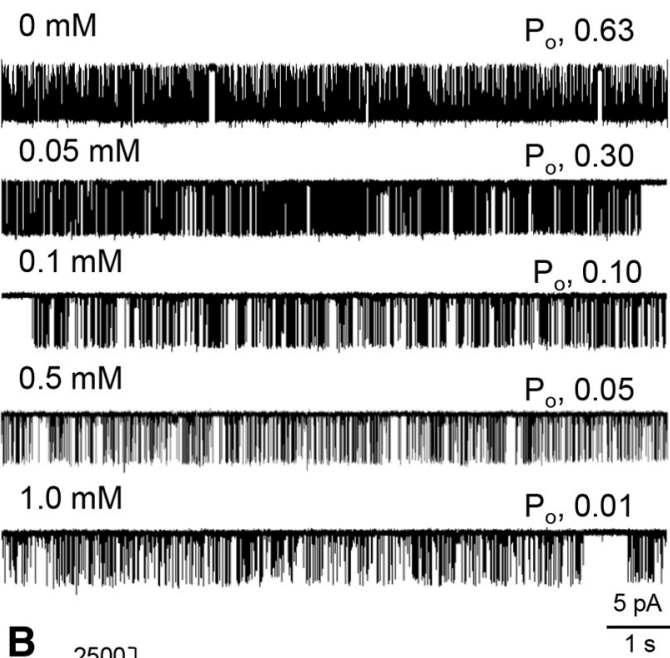

C

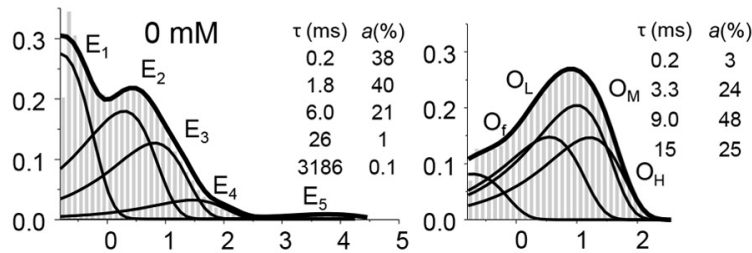

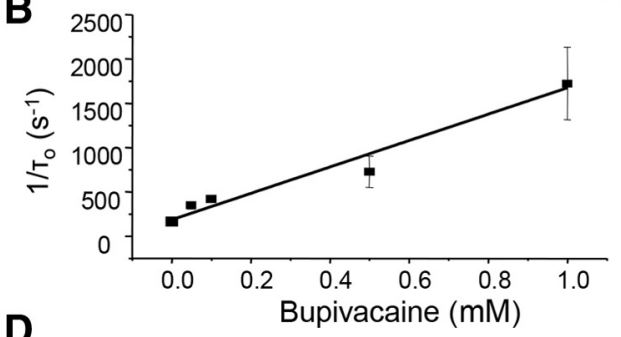

Control $(n=14)$

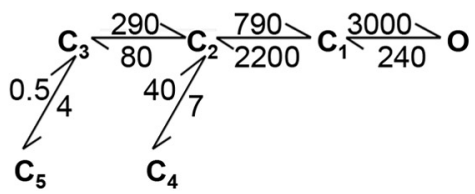

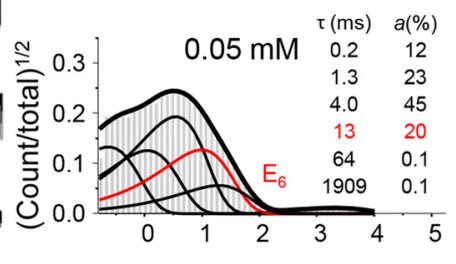
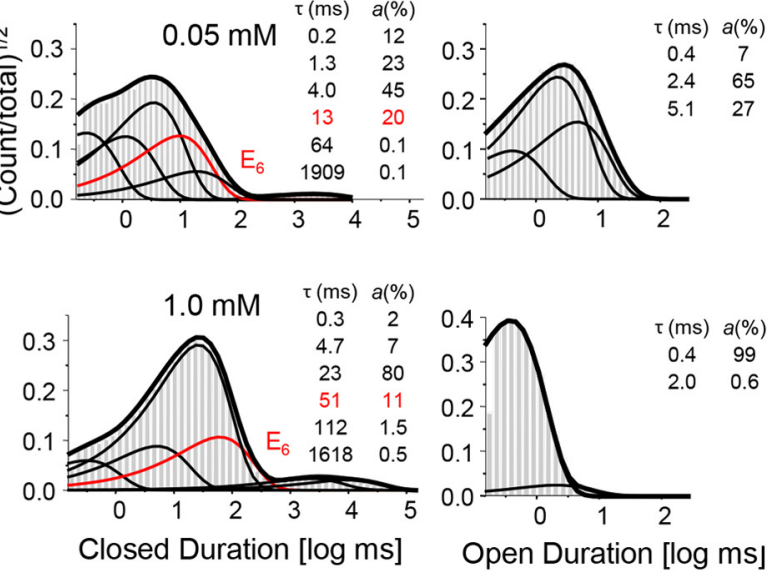

Bupivacaine $(n=12)$

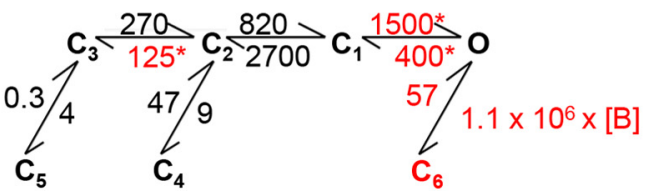

Figure 2. Bupivacaine reduced open durations of single GluN1/GluN2A receptors. $A$, Continuous current traces recorded from one GluN1/GluN2A receptor trapped in a cell-attached patch, with the indicated concentrations of bupivacaine in the recording pipette. $\boldsymbol{B}$, The MOT decreased with increasing bupivacaine concentrations predicting an association rate constant $\mathrm{k}_{\text {on }}=1.5 \times 10^{6} \mathrm{M}^{-1}$ $\mathrm{s}^{-1}$. C, Dwell-time histograms for closed and open intervals detected in the entire record of representative traces obtained with $0 \mathrm{~mm}$ (control), $0.05 \mathrm{~mm}$, and $1.0 \mathrm{~mm}$ bupivacaine. Thin lines indicate exponential components. Insets, Time constants $(\tau)$ and relative areas $(\alpha)$ for these components. Thick lines indicate probability density functions calculated with best-fit state models. $\boldsymbol{D}$, Rate constants $\left(\mathrm{s}^{-1}\right.$, except 0 to $\mathrm{C}_{6}$, which is in $\mathrm{M}^{-1} \mathrm{~s}^{-1}$ ) were optimized by fitting the illustrated $5 \mathrm{C} 10$ (control) or $6 \mathrm{C} 10$ (bupivacaine) kinetic schemes to single-channel data and are given as the rounded values of the mean calculated for each dataset. The GluN1/GluN2A receptor gating mechanism in the presence of bupivacaine was obtained by fitting the $6 \mathrm{C} 10 \mathrm{model} g$ lobally across files obtained at several bupivacaine concentrations and predicted a microscopic dissociation constant $K_{\mathrm{d}}, 52 \mu \mathrm{m} .{ }^{*} p<0.05$, significantly different relative to control rates (Student's $t$ test).

Table 1. Bupivacaine actions on single-channel parameters of GluN1/GluN2A receptors

\begin{tabular}{|c|c|c|c|c|c|c|c|c|}
\hline \multirow[b]{2}{*}{ Bupivacaine (mм) } & \multirow[b]{2}{*}{$n$} & \multicolumn{5}{|l|}{ Entire record } & \multicolumn{2}{|l|}{ Burst } \\
\hline & & $P_{0}$ & Amplitude (pA) & MOT (ms) & MCT (ms) & Events $\left(\times 10^{6}\right)$ & $P_{0}$ & MCT (ms) \\
\hline 0 & 13 & $0.51 \pm 0.03$ & $9.3 \pm 0.1$ & $6.7 \pm 0.6$ & $6.5 \pm 0.8$ & 4.1 & $0.74 \pm 0.01$ & $2.2 \pm 0.1$ \\
\hline 0.05 & 6 & $0.23 \pm 0.06^{*}$ & $10.3 \pm 0.2$ & $3.0 \pm 0.2^{*}$ & $16 \pm 5^{*}$ & 0.9 & $0.42 \pm 0.02^{*}$ & $4.2 \pm 0.3^{*}$ \\
\hline 0.1 & 7 & $0.15 \pm 0.03^{*}$ & $10.2 \pm 0.6$ & $2.3 \pm 0.2^{*}$ & $18 \pm 4^{*}$ & 1.5 & $0.26 \pm 0.04^{*}$ & $7 \pm 1^{*}$ \\
\hline 0.5 & 3 & $0.10 \pm 0.03^{*}$ & $8.7 \pm 0.3$ & $1.4 \pm 0.3^{*}$ & $17 \pm 3^{*}$ & 1.3 & $0.12 \pm 0.03^{*}$ & $13 \pm 2^{*}$ \\
\hline 1 & 6 & $0.04 \pm 0.01^{*}$ & $9.6 \pm 0.5$ & $0.8 \pm 0.2^{*}$ & $34 \pm 10^{*}$ & 0.9 & $0.08 \pm 0.02^{*}$ & $14 \pm 2^{*}$ \\
\hline
\end{tabular}

Data are mean \pm SEM for each dataset.

*Significant difference relative to control ( $p<0.05$, Student's $t$ test).

Effects of bupivacaine on single NMDA receptor kinetics

The low solubility of bupivacaine in high $\mathrm{pH}$ conditions restricted the highest concentration we tested at $\mathrm{pH} 8.0$ to $1.0 \mathrm{~mm}$. Therefore, we recorded on-cell stationary currents from membrane patches containing exactly one active GluN1/GluN2A receptor, with pipette solutions that had subsaturating concentrations of bupivacaine $(0.05-1 \mathrm{~mm})$ and saturating concentrations of glutamate $(1.0 \mathrm{~mm})$ and glycine $(0.1 \mathrm{~mm})$, at $\mathrm{pH} 8.0$. Relative to controls lacking bupivacaine and with increasing bupivacaine concentrations, we observed no changes in the single- channel current amplitude, but the channel open probability $\left(\mathrm{P}_{\mathrm{o}}\right)$ was reduced progressively (Fig. 2; Table 1). At the highest concentration tested $(1 \mathrm{~mm})$, the $\mathrm{P}_{\mathrm{o}}$ was reduced by $92 \%$, and this effect was fully accounted by a combined decrease in mean open time (MOT, by $88 \%$ ) and increase in mean closed time (by 523\%) (Table 1). To investigate the mechanism(s) causing these kinetic changes, we examined the gating kinetics of NMDA receptor in the presence of bupivacaine.

We constructed dwell-time histograms of both the open and closed events. For GluN1/GluN2A receptors, single-channel re- 
Table 2. Bupivacaine actions on closed time components

\begin{tabular}{|c|c|c|c|c|c|c|c|c|c|c|c|c|}
\hline \multirow[b]{2}{*}{ Bupivacaine (mm) } & \multicolumn{12}{|c|}{ Closed components (ms, \%) } \\
\hline & $\tau_{\mathrm{E} 1}$ & $a_{\mathrm{E} 1}$ & $\tau_{\mathrm{E} 2}$ & $a_{\mathrm{E} 2}$ & $\tau_{\mathrm{E} 3}$ & $a_{\mathrm{E} 3}$ & $\tau_{\mathrm{E} 4}$ & $a_{\mathrm{E} 4}$ & $\tau_{\mathrm{E} 5}$ & $a_{\mathrm{E} 5}$ & $\tau_{\mathrm{E} 6}$ & $a_{\mathrm{E} 6}$ \\
\hline 0 & $0.18 \pm 0.01$ & $32 \pm 4$ & $1.9 \pm 0.1$ & $38 \pm 3$ & $5.2 \pm 0.4$ & $29 \pm 3$ & $27 \pm 4$ & $1.36 \pm 0.18$ & $2792 \pm 346$ & $0.14 \pm 0.03$ & - & - \\
\hline 0.05 & $0.20 \pm 0.01$ & $15 \pm 2^{*}$ & $1.4 \pm 0.2^{*}$ & $26 \pm 6$ & $4.1 \pm 0.2$ & $40 \pm 6$ & $152 \pm 64^{*}$ & $0.22 \pm 0.08^{*}$ & $2908 \pm 456$ & $0.37 \pm 0.14^{*}$ & $12.5 \pm 0.6$ & $18 \pm 1$ \\
\hline 0.1 & $0.23 \pm 0.01^{*}$ & $13 \pm 2^{*}$ & $2.2 \pm 0.3$ & $26 \pm 4^{*}$ & $8.0 \pm 1.0^{*}$ & $38 \pm 3$ & $95 \pm 20^{*}$ & $1.69 \pm 1.42$ & $3067 \pm 474$ & $0.34 \pm 0.15$ & $17.1 \pm 1.5 \dagger$ & $30 \pm 6$ \\
\hline 0.5 & $0.24 \pm 0.02^{*}$ & $6 \pm 2^{*}$ & $2.9 \pm 1.0^{*}$ & $14 \pm 2^{*}$ & $11.8 \pm 3.3^{*}$ & $53 \pm 9^{*}$ & $295 \pm 158^{*}$ & $0.16 \pm 0.06^{*}$ & $4636 \pm 1278$ & $0.09 \pm 0.03$ & $26.1 \pm 8.5 \dagger$ & $27 \pm 10$ \\
\hline 1.0 & $0.30 \pm 0.03^{*}$ & $5 \pm 2^{*}$ & $3.5 \pm 0.5^{*}$ & $14 \pm 2^{*}$ & $14.1 \pm 2.2^{*}$ & $67 \pm 9^{*}$ & $149 \pm 57^{*}$ & $0.57 \pm 0.31^{*}$ & $2896 \pm 848$ & $0.32 \pm 0.09^{*}$ & $35.6 \pm 5.4 \dagger$ & $16 \pm 9$ \\
\hline
\end{tabular}

Data are mean \pm SEM for each dataset.

${ }^{*} p<0.05$, significant difference relative to control (Student's $t$ test).

$t p<0.05$, significant difference relative to the first concentration tested ( $0.05 \mathrm{~mm}$ ) (Student's $t$ test).

Table 3. Bupivacaine actions on open time components

\begin{tabular}{|c|c|c|c|c|c|c|c|c|}
\hline \multirow[b]{2}{*}{ Bupivacaine (mм) } & \multicolumn{8}{|c|}{ Open components (ms, \%) } \\
\hline & $\tau_{\text {of }}$ & $a_{\text {of }}$ & $\tau_{\mathrm{L}}$ & $a_{\mathrm{L}}$ & $\tau_{\mathrm{M}}$ & $a_{\mathrm{M}}$ & $\tau_{\mathrm{H}}$ & $a_{\mathrm{H}}$ \\
\hline 0 & $0.19 \pm 0.01$ & $4 \pm 1$ & $3.0 \pm 0.3$ & $32 \pm 6$ & $7.7 \pm 0.5$ & $57 \pm 5$ & $18 \pm 2$ & $12 \pm 2$ \\
\hline 0.05 & $0.34 \pm 0.04$ & $4 \pm 1$ & $2.6 \pm 0.2$ & $73 \pm 9^{*}$ & $5.1 \pm 0.5^{*}$ & $2 \pm 10^{*}$ & - & - \\
\hline 0.1 & $1.38 \pm 0.24^{*}$ & $37 \pm 10^{*}$ & $2.8 \pm 0.2$ & $63 \pm 10^{*}$ & - & - & - & - \\
\hline 0.5 & $1.24 \pm 0.17^{*}$ & $56 \pm 29^{*}$ & $2.4 \pm 0.04$ & $31 \pm 2$ & - & - & - & - \\
\hline 1.0 & $0.70 \pm 0.14^{*}$ & $91 \pm 8^{*}$ & $1.8 \pm 0.1^{*}$ & $1 \pm 0.2^{*}$ & - & - & - & - \\
\hline
\end{tabular}

Data are mean \pm SEM for each dataset.

${ }^{*} p<0.05$, significant difference from control (Student's $t$ test).

cords are well represented with five closed components $\left(E_{1}-E_{5}\right)$ and 2,3, or 4 open components, depending on the number of kinetic modes captured in each file (Popescu and Auerbach, 2003; Kussius et al., 2009; Popescu, 2012). In the presence of bupivacaine, we observed two major changes: (1) closures were longer and the closed time distributions required an additional $\left(\mathrm{E}_{6}\right)$ component for proper fit; and (2) the openings were generally shorter and the open distributions lost longer components progressively (Fig. 2C; Tables 2 and 3). Except for the longest closed component $\left(\mathrm{E}_{5}\right)$, which represents dwells in desensitized conformations, all closed components, including $\mathrm{E}_{6}$, increased in duration with increasing bupivacaine concentrations. The loss of long open components, as well as the detection of an additional closed component in the presence of bupivacaine, is strongly indicative of a channel block mechanism, as classically described for $\mathrm{Mg}^{2+}$ (Nowak et al., 1984; Popescu and Auerbach, 2003).

Two classes of channel blockers are well characterized: "footin-the-door" sequential blockers, which after accessing their binding site(s) within the pore prevent gate closure, and "trapping" blockers, which remain in the pore even after the gate closes. By not permitting channel closure, foot-in-the-door open-channel blockers extend the burst length, whereas trapping blockers have no effect on burst duration (Neher and Steinbach, 1978; Antonov and Johnson, 1996). To investigate the burst length and structure, we defined bursts with a critical time method by excluding events that belonged to the $\mathrm{E}_{4}$ and $\mathrm{E}_{5} \mathrm{com}$ ponents (see Materials and Methods) (Magleby and Pallotta, 1983). Relative to control conditions, bupivacaine (1.0 mM) reduced the open probability within bursts to the same extent $(89 \%)$ as it reduced the open probability in full records (92\%). This result is consistent with the observation that bupivacaine did not affect the duration of longest closed component $\left(\mathrm{E}_{5}\right)$. This analysis also revealed that indeed burst durations increased in duration with increasing bupivacaine concentrations, and at all concentrations the bupivacaine-induced closure was detected within the burst (Table 1). Based on these results, we conclude that, at least in part, bupivacaine reduced NMDA receptor responses by an open-channel foot-in-the-door blocking mechanism.

\section{Model for bupivacaine inhibition}

To model the single-channel data obtained in the presence of bupivacaine, we added an additional closed state $\left(\mathrm{C}_{6}\right)$ to a $5 \mathrm{C} 1 \mathrm{O}$ kinetic scheme, which was validated previously for NMDA receptor gating (Kussius et al., 2009). A statistical ranking of models where the $\mathrm{C}_{6}$ state was appended in turn to each closed state within the control model indicated that the model with the extra closed state appended to the aggregated open state was the most probable (Fig. 2D). This model is consistent with a kinetic mechanism of open-channel block. Next, we fit this $6 \mathrm{C} 1 \mathrm{O}$ model globally to single-channel data obtained at several bupivacaine concentrations ( $n=3$ for each $0.05,0.1,0.5$, and $1.0 \mathrm{~mm}$ ). This analysis produced rate constants for all transitions explicit in the model and indicated that in addition to the $\mathrm{O} \leftrightarrow \mathrm{C}_{6}$ transition, which represents the blocking action of bupivacaine, the opening transition $\left(\mathrm{C}_{1} \leftrightarrow \mathrm{O}\right)$ was also sensitive to bupivacaine concentration. This observation implies that a simple blocking mechanism is insufficient to account for the observed decrease in open durations, and an allosteric effect also contributes substantially to reducing channel $\mathrm{P}_{\mathrm{o}}$. Notably, receptor desensitization kinetics $\left(\mathrm{C}_{2} \leftrightarrow \mathrm{C}_{4}\right.$ and $\left.\mathrm{C}_{3} \leftrightarrow \mathrm{C}_{5}\right)$ remained unchanged relative to control conditions, consistent with a mechanism where all bupivacaineinduced changes occurred within bursts (Fig. 2D). In summary, the results of our single-channel analyses support the notion that bupivacaine reduced NMDA receptor responses with a combined mechanism: it obstructed the permeation pathway with a footin-the-door open-channel blocking mechanism, and it reduced channel gating kinetics, with an allosteric mechanism.

An important feature of open-channel blockers is their voltage dependence. Previous reports found that bupivacaine inhibition of NMDA receptors lacked voltage dependence. However, our single-channel records obtained at a membrane voltage of $\sim-120 \mathrm{mV}$ indicated much stronger inhibition than expected based on whole-cell currents recorded at $-70 \mathrm{mV}$. For example, the microscopic binding and dissociation rate constants for bupivacaine, determined by fitting the model to single-channel data, were as follows: $k_{\text {on }}, 1.1-1.5 \times 10^{6} \mathrm{M}^{-1} \mathrm{~s}^{-1}$ and $k_{\text {off }}, 57.1$ $\mathrm{s}^{-1}$. These values are $\sim 100$-fold and fivefold faster, respectively, than the apparent rate constants estimated from whole-cell cur- 
A

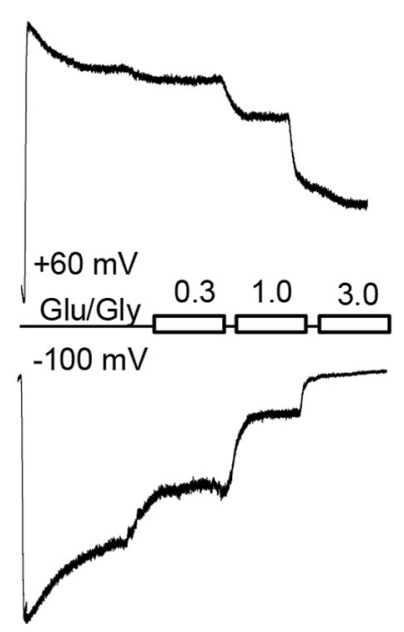

B
I (pA)

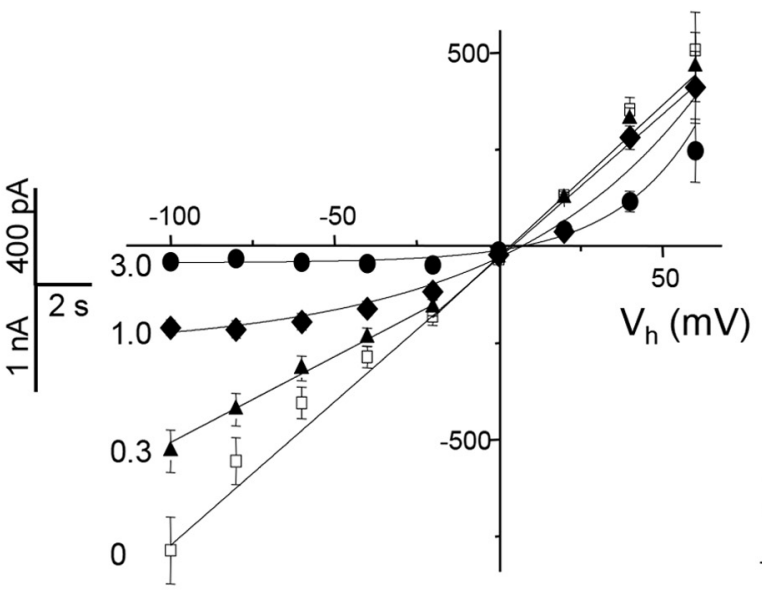

C

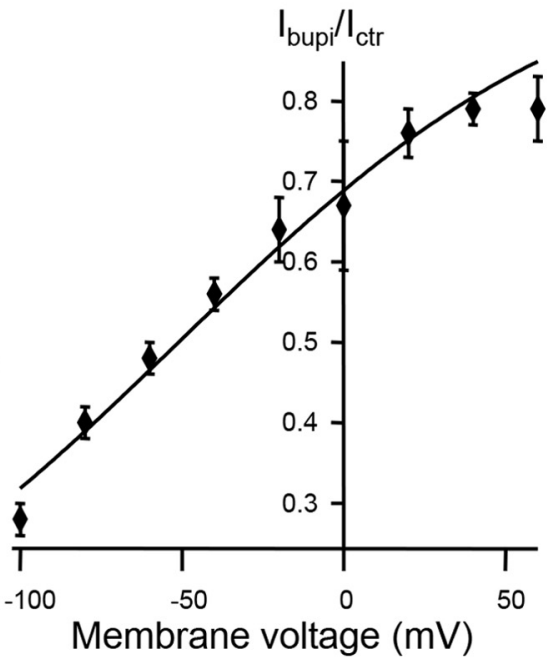

D $\quad 0.1 \mathrm{mM}$ bupivacaine

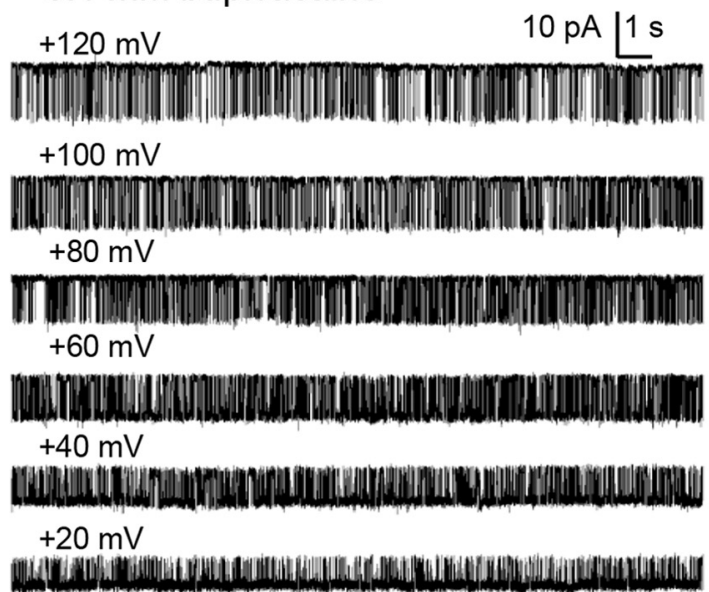

$\mathbf{E}$

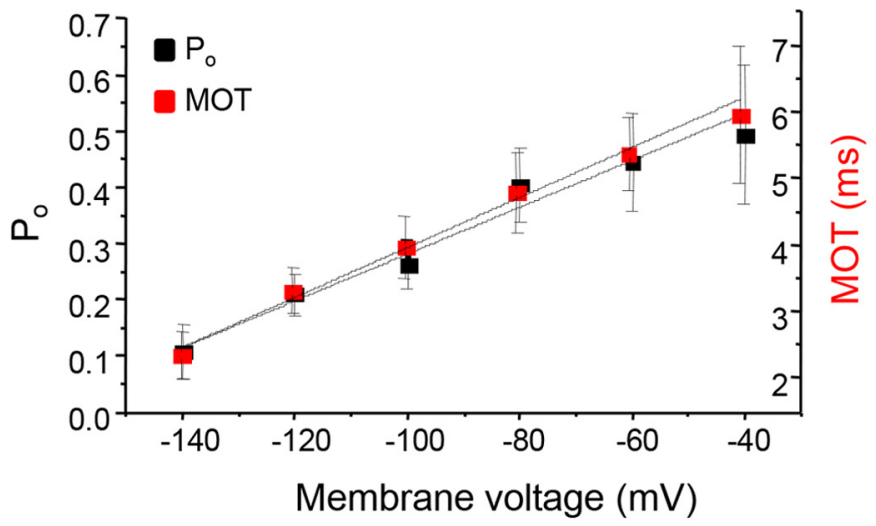

Figure 3. Voltage dependence of bupivacaine inhibition. $\boldsymbol{A}$, Representative whole-cell currents obtained with $1.0 \mathrm{~mm} \mathrm{Glu}$ and $0.1 \mathrm{~mm}$ Gly at -100 and $60 \mathrm{mV}$ holding potentials, pH 7.4 , without or with $0.3,1.0$, or 3.0 mm bupivacaine applied as indicated. $\boldsymbol{B}$, Current-voltage (I-V) relationships for steady-state responses ( $n>4$ ) obtained without (control, open squares) or with increasing concentrations of bupivacaine (filled symbols). C, Voltage dependence of the relative reduction in current by 1.0 mm bupivacaine; the fitted Woodhull function (line) predicts strong voltage dependence of inhibition, $\delta=0.62 \pm 0.03$. D, Voltage dependence of current obtained from one GluN1/GluN2A receptor with 0.1 mm bupivacaine in the recording pipette, at different applied pipette potentials $\left(n=3\right.$, pH 8.0). $\boldsymbol{E}$, Similar voltage dependence of single-channel activity evaluated with open probability $\left(P_{0}\right)$ and MOT.

rents (Fig. $2 B, D$ ). While a blocking mechanism does not explain a voltage dependency for the dissociation rate constant, because overall the dissociation constant predicted by single-channel measurements $(\sim 50 \mu \mathrm{M},-120 \mathrm{mV})$ was $\sim 25$-fold lower than whole-cell measurements $(1.5 \mathrm{~mm},-70 \mathrm{mV})$ (Fig. $1 C, D)$, we next investigated the possibility that bupivacaine inhibition of NMDA receptors may be voltage-dependent.

\section{Voltage dependence of bupivacaine inhibition}

We recorded glutamate-elicited whole-cell responses at a range of holding potentials $(-100 \mathrm{mV}$ to $60 \mathrm{mV})$ in three bupivacaine concentrations $(0.3,1.0$, and $3.0 \mathrm{~mm}$ ) (Fig. $3 A$ ) and determined current-voltage (I-V) dependencies at each concentration (Fig. $3 B$ ). This analysis indicated increasing deviations from linearity with increasing bupivacaine concentrations. By fitting the fractional inhibition observed at $1 \mathrm{~mm}$ as a function of voltage, we found that the membrane voltage increment that caused an e-fold change was $41 \mathrm{mV}$, and the Woodhull equation predicted that the bupivacaine binding site would reside two-thirds within the electrical field ( $\delta=0.62 \pm 0.03$; Fig. $3 C$ ). Given that the $\delta$ for $\mathrm{Mg}^{2+}$ ranges between 0.6 and 1.0 (Ascher and Nowak, 1988; Jahr and Stevens, 1990; Zhu and Auerbach, 2001), our results suggest that bupivacaine binds at or above the $\mathrm{Mg}^{2+}$ binding site, which is formed by asparagine residues that also define the narrowest portion of the pore (Wollmuth et al., 1998). A majority of NMDA receptor open-channel blockers (ketamine, PCP, MK-801) interact with the $\mathrm{Mg}^{2+}$ binding site (Yamakura et al., 1993). However, bupivacaine appears to bind at a site that is distinct from the $\mathrm{Mg}^{2+}$ binding site.

Sugimoto et al. (2003) showed that macroscopic responses recorded from a mutant NMDA receptor that lacks $\mathrm{Mg}^{2+}$ sensitivity remained sensitive to bupivacaine. To test this observation on a microscopic level, we recorded on-cell one-channel currents from GluN1/GluN2A(N615G) receptors (Wollmuth et al., 1998), which are also $\mathrm{Mg}^{2+}$-insensitive, but have reduced gating kinetics (Amico-Ruvio et al., 2011). By comparing our results obtained with $0.1 \mathrm{~mm}$ bupivacaine $(n=9)$ with values previously reported by Amico-Ruvio et al. (2011) in the absence of bupivacaine, we 
found that $\mathrm{P}_{\mathrm{o}}$ and MOT were each reduced $\sim 70 \%$, an effect very similar to that observed for wild-type receptors with this concentration (Table 1). Therefore, although bupivacaine appears to bind deep within the membrane field, the molecular determinants of this binding site are distinct from those for $\mathrm{Mg}^{2+}$ and several other blockers.

To investigate the voltage dependence of single-channel current inhibition, we obtained on-cell current records with $0.1 \mathrm{~mm}$ bupivacaine (twofold the microscopic $\mathrm{K}_{\mathrm{d}}$ ) (Fig. 3D) with pipette potentials ranging between 120 and $20 \mathrm{mV}$. These corresponded to a calculated membrane potential of $\sim-135 \mathrm{mV}$ to $-35 \mathrm{mV}$, given that the resting membrane potential for HEK293 cells in identical conditions is $-15 \pm 2 \mathrm{mV}$ (Borschel et al., 2012). Upon membrane depolarization, we observed strong activity disinhibition. The open probability $\mathrm{P}_{\mathrm{o}}$ and MOT were directly correlated with the calculated membrane voltage (Fig. 3E). These results are consistent with the modeling results and represent further evidence that bupivacaine is an open-channel blocker. In addition, we observed that with $0.1 \mathrm{~mm}$ bupivacaine, at membrane potentials weaker than $-60 \mathrm{mV}$, the channel kinetics were indistinguishable from control ( $0 \mathrm{~mm}$ bupivacaine) $(n=8$, data not shown). This results indicate that both the blocking and gating effects were voltage-dependent.

\section{Bupivacaine blocking mechanism}

Next, to determine whether the allosteric effect may originate from occasional trapping of bupivacaine in the pore, thus accounting for altered channel gating, we used a classic doublepulse whole-cell current experiment (MacDonald et al., 1991; Blanpied et al., 1997; Bolshakov et al., 2003; Kotermanski et al., 2009) (Fig. 4A). First, we applied glutamate (in the presence of glycine) to elicit a peak current and allowed this to relax to steadystate levels; next, we pulsed the cell for $3 \mathrm{~s}$ with saturating bupivacaine $(10 \mathrm{~mm})$ and at the end of the pulse, we also removed glutamate to allow channel closure; a subsequent, second pulse of glutamate was applied to estimate the extent of trapping as the decrease in the responses to this second pulse relative to the initial, naive peak. First, we observed that, when glutamate and bupivacaine were removed simultaneously, a tail current developed, indicating that, upon bupivacaine dissociation, a substantial fraction of channels passed through open conductive conformations before losing glutamate. This observation is consistent with the reaction mechanism illustrated in Figure 2D and further substantiates a foot-in-the-door blocking mechanism for bupivacaine. Second, we found that the second pulse of glutamate produced as much current as the first: $-1.1 \pm 0.3 \mathrm{nA}$ versus $-1.3 \pm 0.4 \mathrm{nA}$, respectively ( $p>0.05$, paired Student's $t$ test), indicating that at the time of the second pulse all channels were bupivacaine-free. Therefore, unlike trapping blockers, such as MK-801, phencyclidine, or ketamine (MacDonald et al., 1991), bupivacaine did not become trapped by gate closure. These results indicate that bupivacaine dissociated at least from some channels while these were open, as indicated by the resurgent current. However, it is also possible that bupivacaine dissociated from closed receptors as well.

Because bupivacaine is lipophilic and thus, membranepermeable, it is conceivable that the drug has dual access to its inhibitory site(s). To address this possibility, we recorded wholecell currents when bupivacaine was either coapplied or preapplied relative to glutamate (Fig. 4B, left; Table 4). As expected, coapplication of bupivacaine and glutamate $(5 \mathrm{~s})$ resulted in a peak response $\left(\mathrm{I}_{\mathrm{pk}}\right)$ slightly but significantly smaller than glutamate-only elicited currents; in addition, we observed an ac-
A

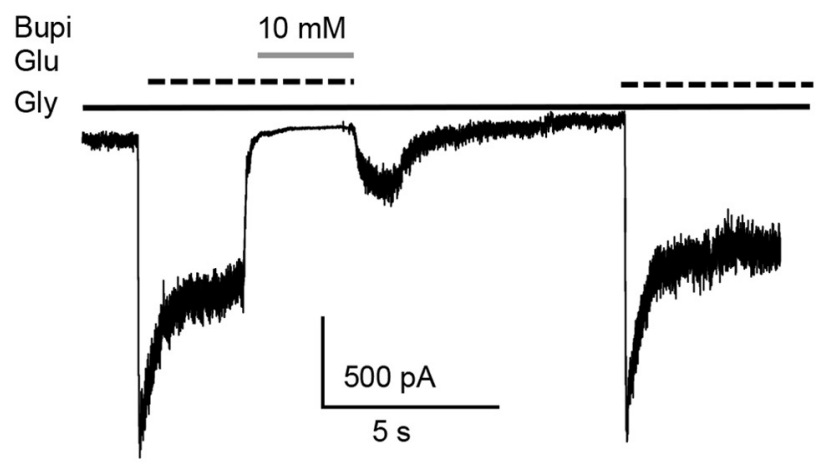

B experimental simulation
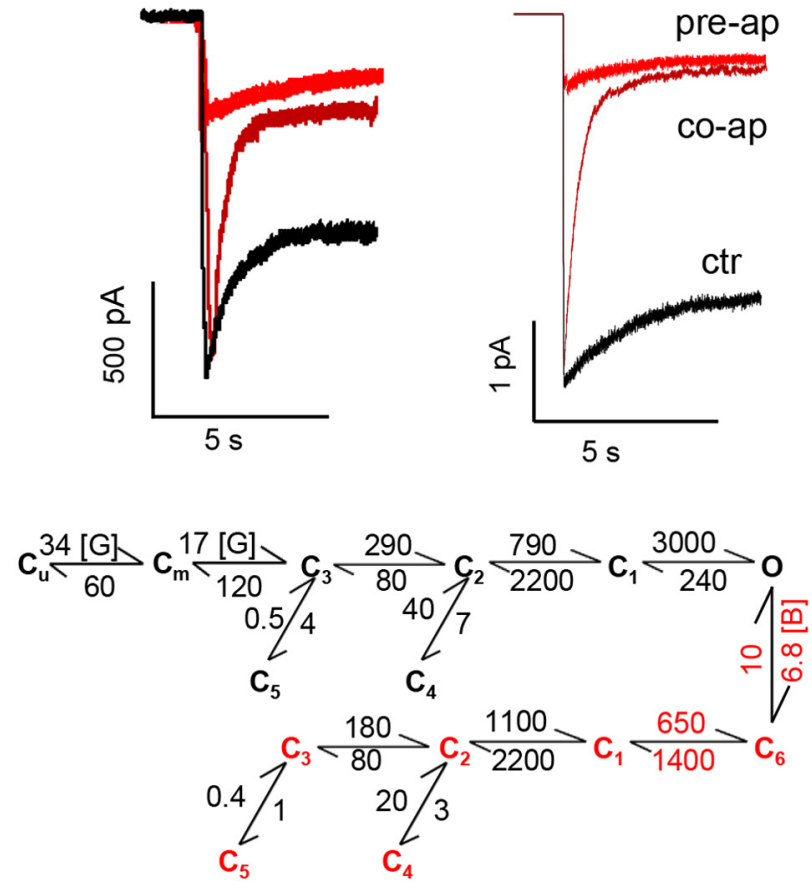

Figure 4. Blocking mechanism and state dependence of bupivacaine's inhibition. $A$, Doublepulse protocol evaluation of bupivacaine's blocking mechanism ( $-100 \mathrm{mV}$, pH 7.4). Simultaneous withdrawal of agonist and bupivacaine produced a resurgent current, consistent with relief from open-channel block; the second pulse elicited responses of similar amplitude as the first, thus indicating complete recovery from bupivacaine inhibition. $\boldsymbol{B}$, Left, Whole-cell responses $(-100 \mathrm{mV}, \mathrm{pH} 8.0)$ were elicited by glutamate $(1.0 \mathrm{~mm})$ application: in the absence of bupivacaine (ctr, black), together with bupivacaine ( $1 \mathrm{M}, \mathrm{co}$-ap, dark red), or during continuous application of bupivacaine (1 mM, pre-ap, red). Right, Macroscopic current traces were simulated from 500 channels (10 pA/each) with glutamate $(1.0 \mathrm{~mm})$ applied: in the absence of bupivacaine (ctr, black), using the control model in Figure $2 D$, left; simultaneously with bupivacaine (1 mm) (co-ap, red), using the tiered model below, which assumes binding and dissociation constants for bupivacaine obtained from whole-cell measurements as in Figure $1 D$; and to receptors pre-equilibrated with bupivacaine $(1.0 \mathrm{~mm}$ ) (pre-ap, red trace), using bupivacainebound model in Figure 2D, right.

celeration of macroscopic desensitization and reduction in the steady-state current level $\left(\mathrm{I}_{\mathrm{ss}}\right)$, consistent with combined poreblock and allosteric gating effects. However, preapplication of bupivacaine resulted in glutamate-elicited responses that were already reduced to steady-state inhibition levels. We observed similar results in outside-out patch recordings, where the solution exchange is much faster, and, thus, unlikely to obscure channel kinetics. When the patch was pretreated with bupivacaine (1.0 $\mathrm{mm})$, glutamate pulses (1.0 mM, $100 \mathrm{~ms}$ ) elicited currents that 
Table 4. State-dependent actions of bupivacaine on macroscopic responses

\begin{tabular}{|c|c|c|c|c|c|c|}
\hline \multicolumn{4}{|l|}{ Experimental } & \multicolumn{3}{|l|}{ Simulation } \\
\hline Condition $(n=6)$ & Peak (pA) & $\operatorname{TauD}(\mathrm{s})$ & $\mathrm{I}_{\mathrm{ss}} / \mathrm{I}_{\mathrm{pk}}$ & Peak (pA) & $\operatorname{TauD}(s)$ & $\mathrm{I}_{\mathrm{ss}} / \mathrm{I}_{\mathrm{pk}}$ \\
\hline Control & $-1006 \pm 231$ & $1.0 \pm 0.1$ & $0.62 \pm 0.06$ & -3517 & 1.4 & 0.76 \\
\hline Coapplication bupivacaine + Glu & $-816 \pm 192^{*}$ & $0.4 \pm 0.03^{*}$ & $0.35 \pm 0.07^{*}$ & -3235 & 0.5 & 0.17 \\
\hline Ambient bupivacaine + Glu application & $-315 \pm 80^{*}$ & $2.0 \pm 0.6$ & $0.68 \pm 0.05$ & -520 & 1.2 & 0.77 \\
\hline
\end{tabular}

Data are mean \pm SEM for each dataset.

${ }^{*} p<0.05$, significant difference from control (Student's $t$ test).

rose approximately twofold slower to a peak that was $45 \%$ smaller, consistent with a mechanism where bupivacaine can bind to closed resting receptors $(n=3)$. Likewise, when bupivacaine was present throughout the experiment, glutamate produced currents with $72 \%$ lower peaks ( $n=3$, data not shown). We did not detect differences in deactivation kinetics between conditions, perhaps due to the low sample size or smaller effects on decay of receptors in excised patches. Together, these results indicate that bupivacaine can bind to and dissociate from both closed and open receptors.

Next, we asked whether the model deduced from microscopic measurements could reproduce the observed macroscopic behaviors. We simulated current traces by applying square pulses of glutamate and bupivacaine, using both the simple blocking model (Fig. 2D) and a tiered model, which consisted of a control arm and a bupivacaine-bound arm connected through the open state (Fig. 4B, bottom). Simulations using the calculated gating changes and the microscopic binding rates deduced from singlechannel experiments overestimated the current inhibition during ambient bupivacaine (simplest blocking model) as well as the suppression of the peak current during simulation of coapplication of bupivacaine and glutamate (tiered model). This discrepancy correlates with the $\sim 10^{2}$-fold difference in the association rate constants measured in the two preparations. For this reason, we used the binding kinetics estimated with macroscopic measurements to attempt to recapitulate the extent of macroscopic inhibition (Fig. 1D). In addition, we corrected these rates to account for the voltage dependence of the bupivacaine-induced kinetic rate changes. Coapplication of bupivacaine and agonist, represented by a tiered model of receptors equilibrated in the control model before transitioning to the bupivacaine-bound model, predicted an increase of the macroscopic desensitization time constant and reduction of the steady-state current. On the other hand, using the simple blocking model illustrated in Figure $2 D$ but using macroscopic binding kinetics, simulations produced lower peak and lower steady-state currents consistent with the levels observed in the whole-cell preparation (Table 4). Although simulations predicted correctly the trend in current change when the timing of bupivacaine application relative to glutamate was changed, we note that the simulations always predicted greater current inhibition, a result that we cannot fully explain but is consistent with increased potency of bupivacaine at the single-channel level. Therefore, the model we developed from single-channel measurements accounted generally for the effects of bupivacaine on macroscopic responses (Fig. $4 B$, right); however, this required to adjust the binding rates to those observed in whole-cell experiments.

\section{Local anesthetic access to the channel}

Next, to determine whether indeed bupivacaine can access its binding site(s) by a lipophilic pathway, we compared its effects with those of QX-314, a permanently charged lidocaine analog that cannot enter the plasma membrane. We applied increasing concentrations of QX-314, pH 7.4, to the steady-state phase of the glutamate-elicited whole-cell currents (Fig. 5A) at several membrane potentials. Responses were reduced in a voltagedependent manner, indicating the presence of an extracellularly accessed binding site within the transmembrane voltage field. Similar to bupivacaine, QX-314 had an $\mathrm{IC}_{50}$ value of $\sim 1 \mathrm{mM}$ $(0.95 \pm 0.21 \mathrm{~mm}$ at $-80 \mathrm{mV})$, and the Woodhull model predicted that the QX-314 binding site was also located approximately twothirds within the voltage field $(\delta=0.63 \pm 0.13)$ (Fig. $5 B)$. Therefore, bupivacaine and QX-314 bind to the same or proximal sites within the channel pore, and this site is accessed by both drugs from the extracellular milieu. This result may indicate that the hydrophilic conduit provides a more rapid access route for bupivacaine; therefore, when applied extracellularly, its actions are not different from those of QX-314.

To investigate whether bupivacaine or QX-314 can reduce receptor currents when applied intracellularly, we recorded glutamate-elicited currents during $2 \mathrm{~s}$ voltage ramps and applied the anesthetics to inside-out excised patches, $\mathrm{pH}$ 7.4. Both drugs reduced inward $\left(\mathrm{Na}^{+}\right)$and outward $\left(\mathrm{Cs}^{+}\right)$currents in a voltagedependent manner. Relative to extracellular applications, higher concentrations of both drugs were needed to achieve comparable inhibition, which indicated that the intracellular binding site(s) may be of lower affinity. Further, in contrast to extracellular applications where both drugs had similar potencies, bupivacaine was more potent than QX-314 in intracellular applications (Fig. $5 C)$. This difference may indicate that bupivacaine, which exists as both charged and neutral forms, can also access its highaffinity extracellular site, through a lipophilic route. From the dependence of the residual current measured at the reported concentrations, fits with the Woodhull equation estimated for bupivacaine and QX-314 distinct fractional penetrations of the electrical field, $\delta=0.35 \pm 0.09$ and $\delta=0.14 \pm 0.06$, respectively. This distinction may indicate distinct intracellular binding site for the two drugs; alternatively, the value obtained for bupivacaine may indicate partial occupancy of the high-affinity extracellular site.

We inspected bursts of single-channel activity measured at several membrane voltages $(20 \mathrm{mV}$ steps, $-100 \mathrm{mV}$ to $60 \mathrm{mV}$ ) from excised inside-out patches containing fewer than three channels with or without bupivacaine or QX-314 (6 mM) to more closely resolve the inhibitory mechanism. At hyperpolarized potentials, both drugs caused a substantial reduction in MOT (Fig. $5 D)$; however, at a depolarizing membrane potential $(60 \mathrm{mV})$ where QX-314 inhibition was completely relieved, bupivacaine still depressed channel MOT to some extent. This difference could be due to the higher potency of bupivacaine inhibition seen at both hyperpolarizing and depolarizing membrane potentials. Reduced sensitivity to these molecules at positive potentials implies an interaction site within the intracellular vestibule. Because of the size of the molecules and maintenance of the reversal potential, it is unlikely that these blocking molecules can permeate the channel; therefore, when applied intracellu- 

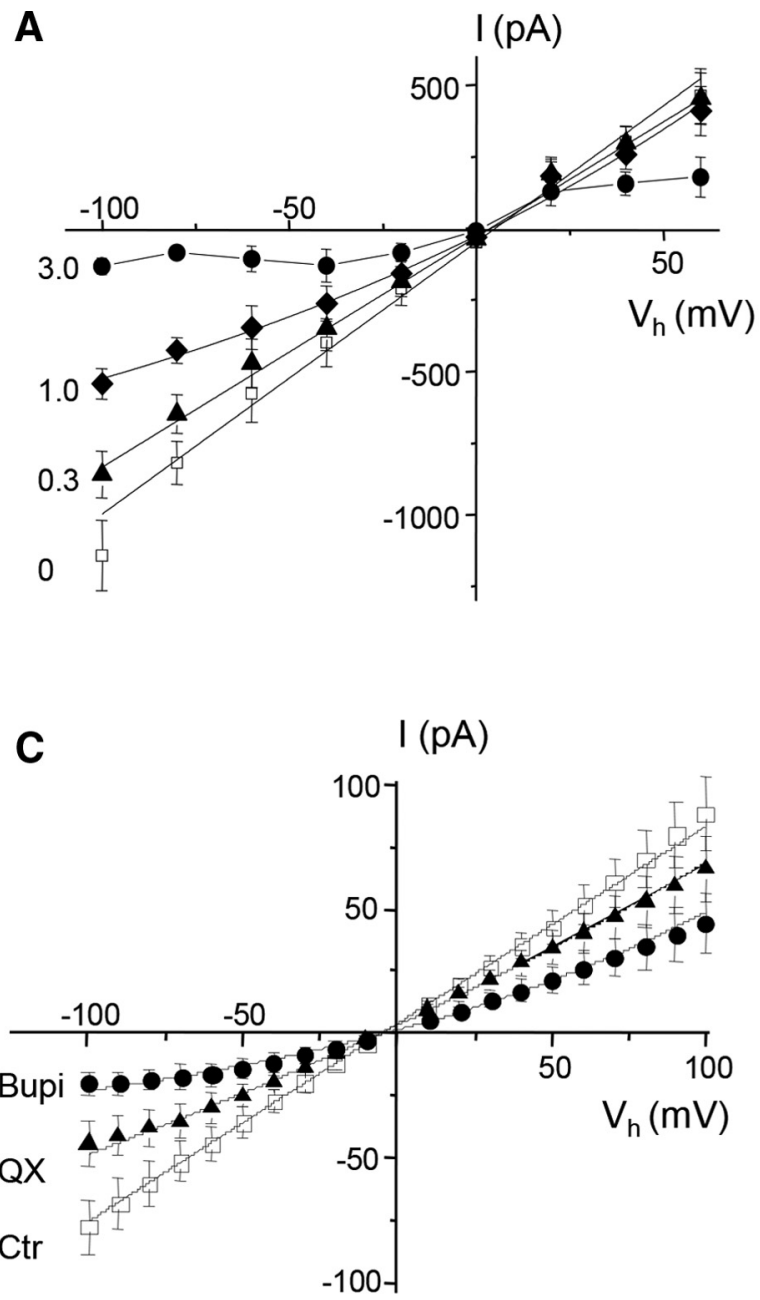

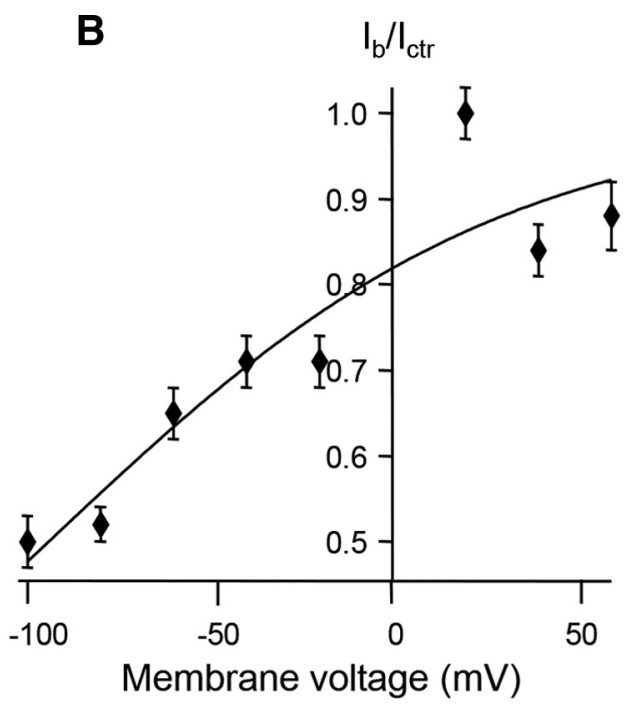

D

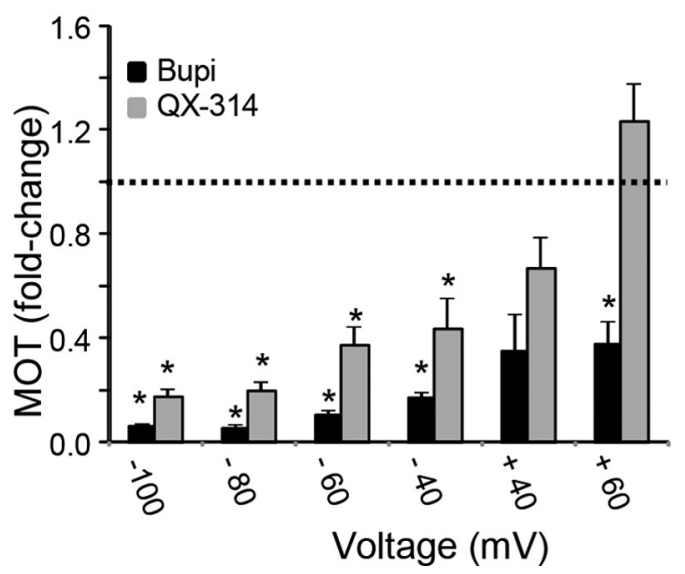

Figure 5. Extracellular and intracellular blockade of GluN1/GluN2A receptors. $A, I-V$ dependencies obtained by plotting whole-cell steady-state amplitudes of current elicited with glutamate (1.0 $\mathrm{mm}, \mathrm{pH}$ 7.4) without (control, open symbols) or with QX-314, a membrane impermeant anesthetic (filled symbols, $0.3,1.0$, and $3.0 \mathrm{~mm}$ ), and recorded at holding potentials between -100 and 60 $\mathrm{mV}$, in $20 \mathrm{mV}$ voltage steps. $\boldsymbol{B}$, Voltage dependence of the relative reduction in current by $Q X-314(1.0 \mathrm{~mm})$; the fitted Woodhull function (line) predicts strong voltage dependence of inhibition, $\delta=$ $0.63 \pm 0.13$. C, Currents from excised inside-out patches were elicited with glutamate $(1.0 \mathrm{M}, \mathrm{pH} 7.4)$ in the recording pipette and were recorded at holding potentials between -100 and $100 \mathrm{mV}$, in $20 \mathrm{mV}$ voltage steps while the inner membrane was exposed to solutions without (Ctr, open squares, $n>9)$ or with QX-314 (6.0 mm, filled triangles, $n=9)$ or bupivacaine (filled circles, $n=8)$. $D$, Voltage dependence of changes in mean open durations measured from excised inside-out patches containing $\leq 3$ channels, produced by bupivacaine $(6.0 \mathrm{~mm}, n>3)$ or $Q X-314(n>4)$. ${ }^{*} p<$ 0.05 , statistically different relative to control (no drug) conditions (Student's $t$ test).

larly, they bind below the selectivity filter. In summary, these results suggest the existence of at least two inhibitory sites, one on either side of the cell membrane that can be accessed by hydrophilic or hydrophobic pathways.

\section{Implication for synaptic currents}

Given that bupivacaine inhibits glutamatergic synaptic transmission in dorsal horn neuronal slices (Furutani et al., 2010), we verified our model's ability to predicted how bupivacaine may affect synaptic physiology. We used a synaptic-like glutamate stimulation and the simplest blocking model with whole-cell binding kinetics as described in a previous section (Figs. 2D and $4 B$ ). We used low-frequency stimulation to replicate transmitter release associated with normal sensation. Voltage-dependent rate constants were corrected for a holding potential of -70 $\mathrm{mV}$. We used $1 \mathrm{~mm}$ bupivacaine, a concentration that lies within reported range of CFS levels (0.1-3.0 mM) achieved after spinal anesthesia with clinical doses of bupivacaine (Ruppen et al., 2009). Upon stimulation with a brief (1 ms) pulse of glutamate $(1 \mathrm{mM})$ in the continuous presence of bupivacaine, the peak current amplitude was reduced by $50 \%$ consistent with the inhibition of NMDA-elicited EPSCs demonstrated by Furutani et al. (2010), in which $2 \mathrm{~mm}$ of bupivacaine resulted in $53 \pm 18 \%$ inhibition; moreover, the deactivation time course was accelerated, such that the overall charge transfer decreased $\sim 70 \%$. Thus, when bupivacaine is used as an anesthetic agent, glutamatergic synapses are suppressed, thus reducing the probability that the synapse will be pathologically potentiated, a process that may underlie the central sensitization that generates chronic pain syndromes.

\section{Discussion}

We report here the first systematic investigation of the actions of bupivacaine on NMDA receptor responses. When applied from 
the extracellular side, bupivacaine reduced channel activity rapidly, reversibly, and in a concentration-dependent manner, by shortening openings and creating new closures. The effects on open durations and the emergence of a concentration-dependent closed component strongly suggested that, in addition to the allosteric mechanism, as proposed previously (Sugimoto et al., 2003), bupivacaine may also act by blocking the channel pore. Indeed, kinetic analyses and modeling were consistent with combined allosteric and open-channel block mechanisms, and the voltage dependence of inhibition indicated that the residues responsible for binding likely reside deep within the membrane field. These residues are distinct from those responsible for $\mathrm{Mg}^{2+}$ block and although readily accessible through a hydrophilic pathway when the channel is open, because bupivacaine can also bind to closed channels (Fig. $4 B$ ), we had to also invoke a lipophilic access route. Finally, when applied from the intracellular side, bupivacaine and the charged anesthetic QX-314, which cannot diffuse in the membrane, inhibited channel responses by binding to residues located below the selectivity filter.

Notably, our conclusions are in contrast with previous reports that proposed that bupivacaine lacks voltage dependence and works indirectly through intracellular signaling pathways (Sugimoto et al., 2003; Hahnenkamp et al., 2006). A possible explanation for this important difference may be the increased kinetic resolution afforded by the present expression system. In this study, we used HEK cells, which because of their smaller size allowed for more precise kinetic assessments of current responses; in addition, our single-channel recordings provided the opportunity for a more rigorous dissection of the molecular mechanisms of bupivacaine actions.

However, even in HEK cells, we observed a disparity between the $\mathrm{IC}_{50}$ and $\mathrm{K}_{\mathrm{d}}$ values as estimated from whole-cell measurements and the $\mathrm{K}_{\mathrm{d}}$ value calculated from modeling single-channel data, indicating that bupivacaine was more effective when evaluated on single-channel currents. The voltage dependence of the block may explain part of the variance because whole-cell and single-channel currents were measured at $-70 \mathrm{mV}$ and -120 $\mathrm{mV}$, respectively. However, this did not fully account for the difference because correcting for voltage did not reconcile the two measurements. Several other studies on channel blockers reported discrepancies in blocker affinities measured with singlechannel versus whole-cell currents.

Blanpied et al. (2005) observed that for amantadine, which is a trapping blocker, the $\mathrm{K}_{\mathrm{d}}$ measured at the single-channel level was greater than the $\mathrm{IC}_{50}$ measured at the whole-cell level. In this case, the difference was accounted for by strong gating effects of the blocker. Thus, both bupivacaine and amantadine present dual inhibitory mechanisms through channel block and allosteric modulation of the gating machinery; an important difference is that bupivacaine does not appear to be trapped in the pore by channel closure. A perusal of the classic literature identified several other reports where foot-in-the-door blockers produced more inhibition on the single-channel signal than on the ensemble whole-cell signal; however, the reason for this discordance remains unclear (Neher and Steinbach, 1978; Hille, 2001; Johnson and Qian, 2002). One explanation may be the large difference in the observations' time scales. Because whole-cell responses are monitored and recorded over several seconds, whereas on-cell unitary currents are observed and averaged over tens of minutes, drugs with dual access pathways may appear more potent in single-channel measurements, where the drug has a chance to fully equilibrate within the membrane, such that the lipophilic conduit also supplies the binding site rather than only serving to deplete it. An alternative explanation may be that, when wholecell responses are measured, the drug is applied to the entire cell surface and more rapidly disperses into the cell where it occupies the low affinity site, whereas in the cell-attached configuration, the drug may preferentially access the hydrophilic high-affinity site. However, the results we present here do not resolve the issue.

Both the amphipathic nature of bupivacaine and bidirectional, extracellular and intracellular, inhibition strongly indicate that bupivacaine travels hydrophilic and hydrophobic paths to access channel binding sites. Summation of the fraction of electric field detected by bupivacaine acting on the extracellular and intracellular compartments reaches nearly $100 \%$, whereas the permanently charged QX-314 adds to only $\sim 77 \%$ of the field. Given the shallower voltage dependence of inhibition through the intracellular binding site and a much lower intracellular affinity detected only for the membrane-impermeable drug, this result may indicate that, unlike QX-314, which is exclusively hydrophilic and, thus, can access only one of the binding sites according to which side of the membrane is applied, bupivacaine can access the high-affinity site regardless of application side. Support of this hypothesis originates from experiments with $\mathrm{Na}^{+}$ channels, where, based on the ionization state of the molecule, the local anesthetic may use hydrophobic and hydrophilic pathways to its binding sites (Hille, 1977).

In contrast, the classic NMDA receptor open channel blocker $\mathrm{Mg}^{2+}$ detects $>100 \%$ of the voltage field. This indicates that, unlike bupivacaine, it can permeate and also interact with other permeating ions. $\mathrm{Mg}^{2+}$ ions represent the most ubiquitous voltage-dependent blocker of NMDA receptors. Extracellular $\mathrm{Mg}^{2+}$ causes a flickering phenotype in single-channel records, with no change in unitary conductance, whereas intracellular $\mathrm{Mg}^{2+}$ causes a reduction in channel conductance, which reflects differences in blocking kinetics (Ascher and Nowak, 1988; Johnson and Ascher, 1990). In contrast, when applied intracellularly, both bupivacaine and QX-314 maintain a flickering-like behavior reflected in the decrease in channel MOT with no change in channel conductance. This may reflect that NMDA receptors are impermeable to these drugs; and regardless of application side, fast dissociation from the blocking site into the bulk solution represents the fastest and most likely dissociation route.

Based on voltage dependence calculations and the appearance of a resurgent current upon simultaneous withdrawal of both agonist and blocker, it is likely that while bound in the pore bupivacaine most often prevents the gate from closing, thus acting with a foot-in-the door mechanism; however, to explain the allosteric effect, which slows rather than prevents closure, we must also envision that, although with lower probability, the gate can close with the drug bound in the pore; however, the drug is not trapped because it can escape through an alternative, even if slower, lipophilic route. Because both the blocking and gating effects have similar voltage-dependencies and are independent of the $\mathrm{Mg}^{2+}$-binding site, our results are consistent with the possibility that they are mediated by the same binding site located above the selectivity filter (Villarroel et al., 1995; Zarei and Dani, 1995; Antonov and Johnson, 1999; Beck et al., 1999; Kashiwagi et al., 2002; Sobolevsky et al., 2002; Sobolevsky et al., 2003; Traynelis et al., 2010). In $\mathrm{Na}^{+}$channels, block by local anesthetics, including bupivacaine, is both voltage- and use-dependent (Courtney, 1975; Ulbricht, 1981). Comparable with bupivacaine microscopic dissociation constant, $\mathrm{Na}^{+}$channel $\mathrm{IC}_{50}$ value is $\sim 30 \mu \mathrm{M}$ (Bräu et al., 1998; Scholz et al., 1998; Nau et al., 1999); therefore, the activity of both the $\mathrm{Na}^{+}$channel and the NMDA receptor is depressed within a similar concentration range at the micro- 
scopic level. The NMDA receptor pore is inverted relative to the $\mathrm{Na}^{+}$channel pore structure. In $\mathrm{Na}^{+}$channels, the binding site of bupivacaine resides below the selectivity filter and encompasses residues in the S6 domain of the channel vestibule, with a phenylalanine (F1764) in the IVS6 contributing most of the energy to the interaction between the channel and the drug (Ragsdale et al., 1994; Catterall, 2000; Yarov-Yarovoy et al., 2001, 2002; Lipkind and Fozzard, 2005). Therefore, scanning the M3 helices of both obligatory subunits for similar bulky hydrophobic residues could help expose bupivacaine's binding site.

Modulators of NMDA receptors provide key insight into their possible therapeutic effects. It has already been demonstrated that glutamatergic synaptic transmission is depressed when bupivacaine is present within the spinal dorsal horn (Furutani et al., 2010). This study has revealed further that, following both lowand high-frequency synaptic stimuli, bupivacaine reduces the NMDA-elicited synaptic response. Hence, heightened synaptic responses in the dorsal horn of the spinal cord during normal pain and sensitizing synaptic transmission may be prevented by bupivacaine to result in loss of sensitivity to pain in acute and chronic conditions. Bupivacaine is widely used for spinal anesthesia, with injections resulting in clinical concentrations ranging from 0.1 to $3 \mathrm{~mm}$ in the CSF of the spinal cord (Ruppen et al., 2009). Similarly, epidural injections produce CSF concentrations of bupivacaine as high at $0.1 \mathrm{~mm}$ (Wilkinson and Lund, 1970). During differential nerve block for chronic pain therapies, $\mathrm{Na}^{+}$ channel conduction is not completely abolished; therefore, because bupivacaine has the ability to access the channel ubiquitously, suppression of current carried by NMDA receptors in the dorsal horn may well contribute to alleviation of chronic pain symptoms. Therefore, this study addresses bupivacaine inhibition in a clinically relevant concentration range and contributes to the understanding of bupivacaine's antagonism of NMDA receptor responses in the spinal cord and its possible value in treating pain conditions.

\section{References}

Amico-Ruvio SA, Murthy SE, Smith TP, Popescu GK (2011) Zinc effects on NMDA receptor gating kinetics. Biophys J 100:1910-1918. CrossRef Medline

Antonov SM, Johnson JW (1996) Voltage-dependent interaction of openchannel blocking molecules with gating of NMDA receptors in rat cortical neurons. J Physiol 493:425-445. Medline

Antonov SM, Johnson JW (1999) Permeant ion regulation of N-methyl-Daspartate receptor channel block by $\mathrm{Mg}(2+)$. Proc Natl Acad Sci U S A 96:14571-14576. CrossRef Medline

Ascher P, Nowak L (1988) The role of divalent cations in the N-methyl-Daspartate responses of mouse central neurones in culture. J Physiol 399: 247-266. Medline

Banke TG, Dravid SM, Traynelis SF (2005) Protons trap NR1/NR2B NMDA receptors in a nonconducting state. J Neurosci 25:42-51. CrossRef Medline

Beck C, Wollmuth LP, Seeburg PH, Sakmann B, Kuner T (1999) NMDAR channel segments forming the extracellular vestibule inferred from the accessibility of substituted cysteines. Neuron 22:559-570. CrossRef Medline

Becker DE, Reed KL (2006) Essentials of local anesthetic pharmacology. Anesth Prog 53:98-108; quiz 109-110. CrossRef Medline

Blanpied TA, Boeckman FA, Aizenman E, Johnson JW (1997) Trapping channel block of NMDA-activated responses by amantadine and memantine. J Neurophysiol 77:309-323. Medline

Blanpied TA, Clarke RJ, Johnson JW (2005) Amantadine inhibits NMDA receptors by accelerating channel closure during channel block. J Neurosci 25:3312-3322. CrossRef Medline

Bolshakov KV, Gmiro VE, Tikhonov DB, Magazanik LG (2003) Determinants of trapping block of N-methyl-D-aspartate receptor channels. J Neurochem 87:56-65. CrossRef Medline
Bormann J (1989) Memantine is a potent blocker of N-methyl-D-aspartate (NMDA) receptor channels. Eur J Pharmacol 166:591-592. CrossRef Medline

Borschel WF, Myers JM, Kasperek EM, Smith TP, Graziane NM, Nowak LM, Popescu GK (2012) Gating reaction mechanism of neuronal NMDA receptors. J Neurophysiol 108:3105-3115. CrossRef Medline

Bräu ME, Vogel W, Hempelmann G (1998) Fundamental properties of local anesthetics: half-maximal blocking concentrations for tonic block of $\mathrm{Na}^{+}$ and $\mathrm{K}^{+}$channels in peripheral nerve. Anesth Analg 87:885-889. CrossRef Medline

Catterall WA (2000) From ionic currents to molecular mechanisms: the structure and function of voltage-gated sodium channels. Neuron 26:13-25. CrossRef Medline

Chen C, Okayama H (1987) High-efficiency transformation of mammalian cells by plasmid DNA. Mol Cell Biol 7:2745-2752. CrossRef Medline

Courtney KR (1975) Mechanism of frequency-dependent inhibition of sodium currents in frog myelinated nerve by the lidocaine derivative GEA. J Pharmacol Exp Ther 195:225-236. Medline

Furutani K, Ikoma M, Ishii H, Baba H, Kohno T (2010) Bupivacaine inhibits glutamatergic transmission in spinal dorsal horn neurons. Anesthesiology 112:138-143. CrossRef Medline

Hahnenkamp K, Durieux ME, Hahnenkamp A, Schauerte SK, Hoenemann CW, Vegh V, Theilmeier G, Hollmann MW (2006) Local anaesthetics inhibit signalling of human NMDA receptors recombinantly expressed in Xenopus laevis oocytes: role of protein kinase C. Br J Anaesth 96:77-87. CrossRef Medline

Hara M, Kai Y, Ikemoto Y (1995) Local anesthetics reduce the inhibitory neurotransmitter-induced current in dissociated hippocampal neurons of the rat. Eur J Pharmacol 283:83-89. CrossRef Medline

Hille B (1977) Local anesthetics: hydrophilic and hydrophobic pathways for the drug-receptor reaction. J Gen Physiol 69:497-515. CrossRef Medline

Hille B (2001) Ion channels of excitable membranes. Sunderland, MA: Sinauer.

Huettner JE, Bean BP (1988) Block of N-methyl-D-aspartate-activated current by the anticonvulsant MK-801: selective binding to open channels. Proc Natl Acad Sci U S A 85:1307-1311. CrossRef Medline

Jahr CE, Stevens CF (1990) A quantitative description of NMDA receptorchannel kinetic behavior. J Neurosci 10:1830-1837. Medline

Ji RR, Woolf CJ (2001) Neuronal plasticity and signal transduction in nociceptive neurons: implications for the initiation and maintenance of pathological pain. Neurobiol Dis 8:1-10. CrossRef Medline

Ji RR, Kohno T, Moore KA, Woolf CJ (2003) Central sensitization and LTP: do pain and memory share similar mechanisms? Trends Neurosci 26: 696-705. CrossRef Medline

Johnson JW, Ascher P (1990) Voltage-dependent block by intracellular $\mathrm{Mg}^{2+}$ of N-methyl-D-aspartate-activated channels. Biophys J 57:10851090. CrossRef Medline

Johnson JW, Qian A (2002) Interaction between channel blockers and channel gating of NMDA receptors. Biol Membrane 19:17-22.

Karakas E, Furukawa H (2014) Crystal structure of a heterotetrameric NMDA receptor ion channel. Science 344:992-997. CrossRef Medline

Kashiwagi K, Masuko T, Nguyen CD, Kuno T, Tanaka I, Igarashi K, Williams K (2002) Channel blockers acting at N-methyl-D-aspartate receptors: differential effects of mutations in the vestibule and ion channel pore. Mol Pharmacol 61:533-545. CrossRef Medline

Kawajiri S, Dingledine R (1993) Multiple structural determinants of voltage-dependent magnesium block in recombinant NMDA receptors. Neuropharmacology 32:1203-1211. CrossRef Medline

Kotermanski SE, Wood JT, Johnson JW (2009) Memantine binding to a superficial site on NMDA receptors contributes to partial trapping. J Physiol 587:4589-4604. CrossRef Medline

Kussius CL, Kaur N, Popescu GK (2009) Pregnanolone sulfate promotes desensitization of activated NMDA receptors. J Neurosci 29:6819-6827. CrossRef Medline

Lee CH, Lü W, Michel JC, Goehring A, Du J, Song X, Gouaux E (2014) NMDA receptor structures reveal subunit arrangement and pore architecture. Nature 511:191-197. CrossRef Medline

Lipkind GM, Fozzard HA (2005) Molecular modeling of local anesthetic drug binding by voltage-gated sodium channels. Mol Pharmacol 68: 1611-1622. CrossRef Medline

MacDonald JF, Bartlett MC, Mody I, Pahapill P, Reynolds JN, Salter MW, Schneiderman JH, Pennefather PS (1991) Actions of ketamine, phency- 
clidine and MK-801 on NMDA receptor currents in cultured mouse hippocampal neurones. J Physiol 432:483-508. Medline

Magleby KL, Pallotta BS (1983) Burst kinetics of single calcium-activated potassium channels in cultured rat muscle. J Physiol 344:605-623. Medline

Maki BA, Cummings KA, Paganelli MA, Murthy SE, Popescu GK (2014) One-channel cell-attached patch-clamp recording. J Vis Exp. Advance online publication. Retrieved Jun 9, 2014. doi: 10.3791/51629. CrossRef Medline

Nau C, Vogel W, Hempelmann G, Bräu ME (1999) Stereoselectivity of bupivacaine in local anesthetic-sensitive ion channels of peripheral nerve. Anesthesiology 91:786-795. CrossRef Medline

Neher E, Steinbach JH (1978) Local anaesthetics transiently block currents through single acetylcholine-receptor channels. J Physiol 277:153-176. Medline

Nishizawa N, Shirasaki T, Nakao S, Matsuda H, Shingu K (2002) The inhibition of the N-methyl-D-aspartate receptor channel by local anesthetics in mouse CA1 pyramidal neurons. Anesth Analg 94:325-330. CrossRef Medline

Nowak L, Bregestovski P, Ascher P, Herbet A, Prochiantz A (1984) Magnesium gates glutamate-activated channels in mouse central neurones. Nature 307:462-465. CrossRef Medline

Parsons CG, Gruner R, Rozental J, Millar J, Lodge D (1993) Patch clamp studies on the kinetics and selectivity of N-methyl-D-aspartate receptor antagonism by memantine (1-amino-3,5-dimethyladamantan). Neuropharmacology 32:1337-1350. CrossRef Medline

Popescu G (2005) Principles of N-methyl-D-aspartate receptor allosteric modulation. Mol Pharmacol 68:1148-1155. CrossRef Medline

Popescu G, Auerbach A (2003) Modal gating of NMDA receptors and the shape of their synaptic response. Nat Neurosci 6:476-483. CrossRef Medline

Popescu GK (2012) Modes of glutamate receptor gating. J Physiol 590:73-91. Medline

Popescu G, Robert A, Howe JR, Auerbach A (2004) Reaction mechanism determines NMDA receptor response to repetitive stimulation. Nature 430:790-793. CrossRef Medline

Qin F, Auerbach A, Sachs F (1996) Estimating single-channel kinetic parameters from idealized patch-clamp data containing missed events. Biophys J 70:264-280. CrossRef Medline

Qin F, Auerbach A, Sachs F (1997) Maximum likelihood estimation of aggregated Markov processes. Proc Biol Sci 264:375-383. CrossRef Medline

Ragsdale DS, McPhee JC, Scheuer T, Catterall WA (1994) Molecular determinants of state-dependent block of $\mathrm{Na}^{+}$channels by local anesthetics. Science 265:1724-1728. CrossRef Medline

Rondón L, Privat AM, Daulhac L, Davin N, Mazur A, Fialip J, Eschalier A, Courteix C (2010) Mg attenuates chronic hypersensitivity and spinal cord NMDA receptor phosphorylation in a rat model of diabetic neuropathic pain. J Physiol 588:4205-4215. CrossRef Medline

Ruppen W, Steiner LA, Drewe J, Hauenstein L, Brugger S, Seeberger MD (2009) Bupivacaine concentrations in the lumbar cerebrospinal fluid of patients during spinal anaesthesia. Br J Anaesth 102:832-838. CrossRef Medline

Scholz A (2002) Mechanisms of (local) anaesthetics on voltage-gated sodium and other ion channels. Br J Anaesth 89:52-61. CrossRef Medline

Scholz A, Kuboyama N, Hempelmann G, Vogel W (1998) Complex blockade of TTX-resistant $\mathrm{Na}^{+}$currents by lidocaine and bupivacaine reduce firing frequency in DRG neurons. J Neurophysiol 79:1746-1754. Medline Shiokawa H, Kaftan EJ, MacDermott AB, Tong CK (2010) NR2 subunits and NMDA receptors on lamina II inhibitory and excitatory interneurons of the mouse dorsal horn. Mol Pain 6:26. CrossRef Medline

Sobolevsky AI, Koshelev SG, Khodorov BI (1999) Probing of NMDA channels with fast blockers. J Neurosci 19:10611-10626. Medline

Sobolevsky AI, Beck C, Wollmuth LP (2002) Molecular rearrangements of the extracellular vestibule in NMDAR channels during gating. Neuron 33:75-85. CrossRef Medline

Sobolevsky AI, Yelshansky MV, Wollmuth LP (2003) Different gating mechanisms in glutamate receptor and $\mathrm{K}^{+}$channels. J Neurosci 23:75597568. Medline

South SM, Kohno T, Kaspar BK, Hegarty D, Vissel B, Drake CT, Ohata M, Jenab S, Sailer AW, Malkmus S, Masuyama T, Horner P, Bogulavsky J, Gage FH, Yaksh TL, Woolf CJ, Heinemann SF, Inturrisi CE (2003) A conditional deletion of the NR1 subunit of the NMDA receptor in adult spinal cord dorsal horn reduces NMDA currents and injury-induced pain. J Neurosci 23:5031-5040. Medline

Sugimoto M, Uchida I, Mashimo T (2003) Local anaesthetics have different mechanisms and sites of action at the recombinant $\mathrm{N}$-methyl-D-aspartate (NMDA) receptors. Br J Pharmacol 138:876-882. CrossRef Medline

Traynelis SF, Wollmuth LP, McBain CJ, Menniti FS, Vance KM, Ogden KK, Hansen KB, Yuan H, Myers SJ, Dingledine R (2010) Glutamate receptor ion channels: structure, regulation, and function. Pharmacol Rev 62:405496. CrossRef Medline

Ueta K, Sugimoto M, Suzuki T, Uchida I, Mashimo T (2006) In vitro antagonism of recombinant ligand-gated ion-channel receptors by stereospecific enantiomers of bupivacaine. Reg Anesth Pain Med 31:19-25. CrossRef Medline

Ulbricht W (1981) Kinetics of drug action and equilibrium results at the node of Ranvier. Physiol Rev 61:785-828. Medline

Villarroel A, Burnashev N, Sakmann B (1995) Dimensions of the narrow portion of a recombinant NMDA receptor channel. Biophys J 68:866875. CrossRef Medline

Wilkinson GR, Lund PC (1970) Bupivacaine levels in plasma and cerebrospinal fluid following peridural administration. Anesthesiology 33:482486. CrossRef Medline

Wollmuth LP, Kuner T, Sakmann B (1998) Adjacent asparagines in the NR2-subunit of the NMDA receptor channel control the voltagedependent block by extracellular $\mathrm{Mg}^{2+}$. J Physiol 506:13-32. CrossRef Medline

Woodhull AM (1973) Ionic blockage of sodium channels in nerve. J Gen Physiol 61:687-708. CrossRef Medline

Woolf CJ (2010) Central sensitization: implications for the diagnosis and treatment of pain. Pain 152 [Suppl 3]:S2-S15.

Yamakura T, Mori H, Masaki H, Shimoji K, Mishina M (1993) Different sensitivities of NMDA receptor channel subtypes to non-competitive antagonists. Neuroreport 4:687-690. CrossRef Medline

Yarov-Yarovoy V, Brown J, Sharp EM, Clare JJ, Scheuer T, Catterall WA (2001) Molecular determinants of voltage-dependent gating and binding of pore-blocking drugs in transmembrane segment IIIS6 of the $\mathrm{Na}(+)$ channel alpha subunit. J Biol Chem 276:20-27. CrossRef Medline

Yarov-Yarovoy V, McPhee JC, Idsvoog D, Pate C, Scheuer T, Catterall WA (2002) Role of amino acid residues in transmembrane segments IS6 and IIS6 of the $\mathrm{Na}^{+}$channel alpha subunit in voltage-dependent gating and drug block. J Biol Chem 277:35393-35401. CrossRef Medline

Zarei MM, Dani JA (1995) Structural basis for explaining open-channel blockade of the NMDA receptor. J Neurosci 15:1446-1454. Medline

Zhu Y, Auerbach A (2001) $\mathrm{Na}(+)$ occupancy and $\mathrm{Mg}(2+)$ block of the $N$-methyl-D-aspartate receptor channel. J Gen Physiol 117:275-286. CrossRef Medline 